\title{
Energy Storage by Sensible Heat for Buildings
}

\author{
Yilin Fan and Lingai Luo
}

\begin{abstract}
This chapter presents a state-of-the-art review on the available thermal energy storage (TES) technologies by sensible heat for building applications. After a brief introduction, the basic principles and the required features for desired sensible heat storage are summarized. Then, material candidates and recent advances on sensible heat or cold storage adapted for building application are discussed, each with its own characteristics, advantages, and limitations. A large section of the chapter is devoted to the sensible TES technologies for buildings, both for short-term (daily) and for long-term (seasonal) storage. Each technology is described in detail including different aspects: basic principle, development status, performance and costs, potential and barriers, today's R\&D activity focus, etc. Comparisons on the advantages and limitations between different TES technologies are also made. Finally, conclusions and future directions are summarized.
\end{abstract}

\section{Keywords}

Thermal energy storage (TES) • Sensible $\bullet$ Building $\bullet$ Storage capacity $\bullet$ Thermal loss $\cdot$ Stratification

\section{Contents}

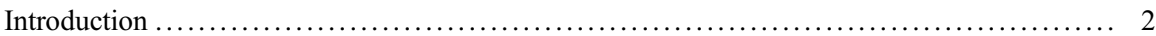

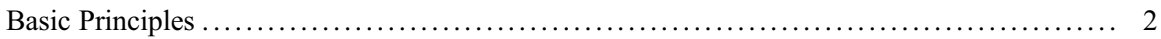

Materials for Sensible Heat or Cold Storage $\ldots \ldots \ldots \ldots \ldots \ldots \ldots \ldots \ldots \ldots \ldots \ldots \ldots \ldots \ldots \ldots .4$

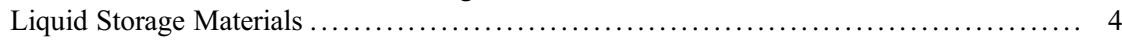

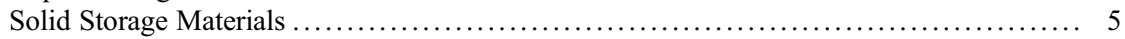

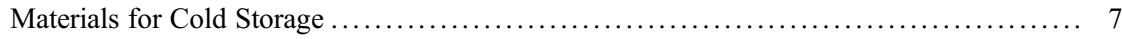

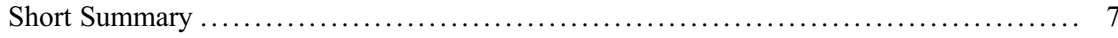

Y. Fan $(\bowtie) \cdot$ L. Luo

Laboratoire de Thermique et Energie de Nantes (LTEN), UMR CNRS 6607, Nantes, France

e-mail: yilin.fan@univ-nantes.fr; lingai.luo@univ-nantes.fr 


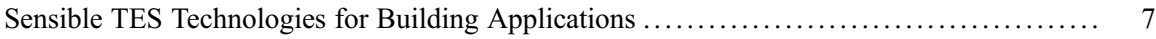

Short-Term Sensible TES Technologies ..................................... 9

Long-Term Sensible TES Technologies .................................... 17

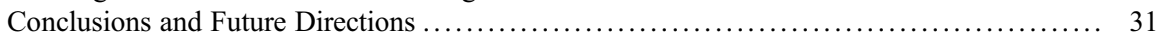

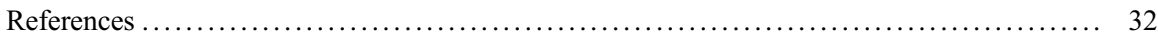

\section{Introduction}

Thermal energy storage (TES) means the temporary holding of excessive thermal energy (in the form of heat or cold) in a storage medium for later use. It helps to balance the mismatch (both in time and in quantity) between heat supply and heat demand. As a result, it plays a more and more important role in various sectors from energy production (e.g., CSP plants) to energy utilization (e.g., buildings), especially for increasing the ratio of renewable energy sources in different countries and regions.

Depending on different technologies, thermal energy can be stored at temperatures between $-40{ }^{\circ} \mathrm{C}$ to more than $400{ }^{\circ} \mathrm{C}$ as sensible heat, latent heat, and thermochemical energy. Sensible heat storage, by its definition, means that thermal energy (heat or cold) is stored in the form of sensible heat in the storage medium, which does not undergo any phase change during charging or discharging process. The single process involved is the temperature variation of the storage medium within one phase. For building applications, TES systems based on sensible heat are currently the most developed and commercially available while latent or thermochemical TES systems are relatively underdeveloped.

This chapter will introduce different TES technologies based on sensible heat for building applications.

\section{Basic Principles}

The amount of thermal energy (J) stored or released within a sensible heat storage process may be expressed by Eq. (1):

$$
Q=\int_{T_{i}}^{T_{f}} m C_{p}(T) d T
$$

where $m$ is the mass of the storage material $(\mathrm{kg}), C_{p}$ the specific heat $\left(\mathrm{J} \cdot \mathrm{kg}^{-1} \mathrm{~K}^{-1}\right), T_{i}$ and $T_{f}$ the initial and final temperature $(\mathrm{K})$ of the storage material, respectively.

The specific heat of certain storage material is usually temperature dependent. However, a constant value of $C_{p}$ allows to make an approximate calculation when its variation is not so big within the temperature range. Equation (1) can then be rewritten as:

$$
Q=m \bar{C}_{p}\left(T_{f}-T_{i}\right)=\rho V \bar{C}_{p}\left(T_{f}-T_{i}\right)
$$


Where $\bar{C}_{p}$ is the average specific heat of the storage material within the temperature range. Note that constant values of density $\rho\left(\mathrm{kg} \cdot \mathrm{m}^{-3}\right)$ are considered for the majority of storage materials applied in buildings. For packed bed or porous medium used for thermal energy storage, however, the porosity of the material should also be taken into account. Then the energy storage density per unit mass or per unit volume of certain material may be calculated as Eq. (3) or Eq. (4), respectively.

$$
\begin{gathered}
Q / m=\bar{C}_{p}\left(T_{f}-T_{i}\right) \\
Q / V=\rho \bar{C}_{p}\left(T_{f}-T_{i}\right)
\end{gathered}
$$

Based on Eqs. 3 and 4, one may observe that high values of $C_{p}$ render a corresponding high energy storage density. It is thus a key parameter for the selection of proper materials for sensible heat storage use.

The required features for desired sensible heat storage may be summarized as follows.

- High storage density: for a certain storage capacity ( $\mathrm{J}$ or $\mathrm{kWh})$, higher storage density requires lower amount of the storage materials $(\mathrm{kg})$ and smaller size of the storage system $\left(\mathrm{m}^{3}\right)$, implying lower capacity cost $(€ / \mathrm{kWh})$ of the storage system.

- High energy efficiency: high proportion of energy stored in the system could be released to the user. This requires reducing the energy loss during the storage period and the charging/discharging cycle. However, the quantity of energy loss depends on many factors, such as the temperature difference between the stored medium and the environment, the storage duration, the insulation, etc.

- Wide operation temperature range: for building application, the working temperature usually ranges between $0-120^{\circ} \mathrm{C}$, except for some specific purposes (e.g., $>120{ }^{\circ} \mathrm{C}$ when combined with high temperature solar panels or $<0{ }^{\circ} \mathrm{C}$ for icemaking). For a certain application, one often searches for a wide temperature variation but without phase change or decomposition of the storage materials.

- Fast charging and discharging: less time is needed to reach the storage capacity. This often calls for efficient/intensified heat transfers inside the storage medium (high thermal conductivity, convection effect, etc.) as well as between the storage medium and the heat transfer fluids (large temperature difference, efficient design of the flow paths for the storage unit, etc.).

- Good stability of the storage material: for short-term storage (hourly, daily, weekly), it means low degradation of the storage material under hundreds or thousands of thermal cycling; for long-term storage (seasonal), it means stable thermo-physical properties of the storage material during the storage period. On the whole, long lifetime of the storage material (thus reduced capital cost) is favorable.

- Low or noncorrosiveness, environmental friendly, and inflammableness: this means good compatibility with the construction around and the environment as a whole, as well as the safety issues. 
- Low cost: which refers to either low capacity cost $(€ / \mathrm{kWh})$ or low power cost $(€ /$ $\mathrm{kW}$ ) of the storage system. It depends also on various factors such as the availability of the storage materials, the capital and operational costs of the storage unit and accessories, and their lifetime.

It should be noted that the above-mentioned features are usually interdependent. And most likely, a sensible heat storage system/technique can not necessarily meet all the requirements. For example, thicker insulation layer could effectively reduce the heat loss but also augments the size of the storage unit and the capital cost. Therefore, some trade-offs or compromises should be made when dealing with specific energy storage issues in buildings. Some multi-objective optimization methods (e.g., [1, 90]) have also been developed which may be associated with life cycle analysis (LCA) or techno-economic analysis.

\section{Materials for Sensible Heat or Cold Storage}

A great number of materials have been investigated and proposed for the purpose of sensible heat storage. New materials are also developed every year, which should be further studied for characterizing their properties. Based on their physical status, sensible heat storage materials may be categorized by liquid, solid and gaseous media. Compared to liquid and solid materials, which are widely used for building applications, gaseous materials are rarely used mainly due to their low density thus large volume of reservoirs needed. In this section of the chapter, different materials used for the storage of thermal energy (both heat and cold) in buildings will be discussed, each with its own characteristics, advantages and limitations.

\section{Liquid Storage Materials}

Various liquid materials are used for sensible heat storage in buildings, each having its proper operational temperature range. Among them, water is the most commonly used liquid because it meets almost all the aforementioned required features: availability and accessibility, low cost, relatively high specific heat, environmental friendly, stable under cycling operations, etc. Moreover, its operational temperature range (about $20-90^{\circ} \mathrm{C}$ ) covers a large amount of heating demands for buildings, such as space heating and hot water production. Under atmospheric pressure, the storage temperature limit for water should be below $100{ }^{\circ} \mathrm{C}$. Higher storage temperature above $100{ }^{\circ} \mathrm{C}$ is still possible but pressurized tanks should be used. Water can be used in different storage techniques for buildings in terms of storage duration, such as hot water tanks for short-term storage and aquifer or solar ponds for seasonal storage.

Organic oils (e.g., alcobolic or alkane solutions) sometimes appear as alternative to water, so as to achieve a higher working temperature above $100{ }^{\circ} \mathrm{C}$ (e.g., up to $118^{\circ} \mathrm{C}$ for butanol; up to $126^{\circ} \mathrm{C}$ for octane; up to $148^{\circ} \mathrm{C}$ for pentanol; up to $160^{\circ} \mathrm{C}$ 
for engine oil; etc.). Compared to water, however, they usually have smaller $C_{p}$ (typically from 2 to $3 \mathrm{~kJ} \cdot \mathrm{kg}^{-1} \mathrm{~K}^{-1}$ ) and lower thermal conductivity $k$ (typically from $0.1-0.2 \mathrm{~W} \cdot \mathrm{m}^{-1} \mathrm{~K}^{-1}$ ), implying lower storage density and poorer heat transfer. Other disadvantages such as the degradation problem and the fire risk when working at high temperature are also identified. Therefore, their utilization is recommended only with caution.

Heat transfer fluids (HTFs) can also be used as liquid storage materials (e.g., [2, 3]). Contrary to the aforementioned pure liquids, they are usually the mixture of synthetic substances. Some commercialized products exist on the market, such as XCELTHERM $^{\circledR}$, THERMINOL ${ }^{\circledR}$, DURATHERM ${ }^{\circledR}$, DOWTHERM ${ }^{\circledR}$, PARATHERM $^{\circledR}$, etc., each having a series of candidates with different thermo-physical properties. The interesting feature is that their working temperature could generally exceed $100{ }^{\circ} \mathrm{C}$, so they are mostly used in building-integrated solar energy systems. However, the relatively high cost (with respect to water) also limits their use only in small-sized systems.

Molten salts, liquid metals, and liquid glasses can also be used as HTF as well as sensible storage materials, but for high temperature applications $\left(>150^{\circ} \mathrm{C}\right)$. Hence their intended use fits more the solar thermal power plants rather than for buildings directly.

Table 1 shows a list of liquid materials used or have the potential to be used in sensible heat storage systems for buildings.

\section{Solid Storage Materials}

Solid materials are also widely used for the storage of sensible heat for buildings. The building structure itself (concrete, brick, steel, glass, wood, etc.) plays the role as a thermal buffer to attenuate the interior temperature variation using the building thermal inertia [8]. Other common uses are the pecked beds of rocks or pebbles combined with solar energy systems for space heating, the ground and soil storage (such as Chinese Kang). Generally, these solid materials are structured to provide heat transfer surfaces (direct contact) for the HTFs during charging or discharging. Compared to liquid storage materials, solid materials exhibit the advantages like nontoxic, nonflammable, no leakage problem, and thermally more stable. The major drawback is their low specific heat capacity (generally about $1 \mathrm{~kJ} . \mathrm{m}^{-3} \mathrm{~K}^{-1}$ ), implying low energy density of the storage systems.

Concretes, stones, or sands could usually provide an operating temperature range between $20{ }^{\circ} \mathrm{C}$ to $70{ }^{\circ} \mathrm{C}$. Their cost as storage media is acceptable due to their abundant availability. Metals such as aluminum, iron, and copper could be used for high temperature storage applications over $160{ }^{\circ} \mathrm{C}$. They also exhibit good heat conduction property, two or three orders of magnitude higher (e.g., $73 \mathrm{~W} \cdot \mathrm{m}^{-1} \mathrm{~K}^{-1}$ for iron, $204 \mathrm{~W} \cdot \mathrm{m}^{-1} \mathrm{~K}^{-1}$ for aluminum, $385 \mathrm{~W} \cdot \mathrm{m}^{-1} \mathrm{~K}^{-1}$ for copper, etc.) than that of liquid storage materials. Nevertheless, they may be chemically less stable due to the possible interactions with the HTFs. In terms of cost, they are not naturally available thus should be refined, a factor that also prohibits their large-scale use. 
Table 1 Thermo-physical properties of some liquid materials for sensible heat storage in buildings

\begin{tabular}{|c|c|c|c|c|c|}
\hline Material & $\begin{array}{l}\text { Temperature } \\
\text { range } \\
\left({ }^{\circ} \mathrm{C}\right) \\
\end{array}$ & $\begin{array}{l}\text { Density } \\
\rho \text { (kg. } \\
\mathrm{m}^{-3} \text { ) }\end{array}$ & $\begin{array}{l}\text { Specific heat } \\
C p(\mathrm{~kJ} . \\
\left.\mathrm{Kg}^{-1} \mathrm{~K}^{-1}\right)\end{array}$ & $\begin{array}{l}\text { Thermal } \\
\text { conductivity } \\
k\left(\mathrm{~W} \cdot \mathrm{m}^{-1} \mathrm{~K}^{-1}\right) \\
\text { at } 20^{\circ} \mathrm{C}\end{array}$ & Reference \\
\hline Water & $0-100$ & 1000 & 4.19 & 0.58 & - \\
\hline Ethanol & Up to 78 & 790 & 2.4 & 0.171 & - \\
\hline Propanol & Up to 97 & 800 & 2.5 & 0.161 & - \\
\hline Butanol & Up to 118 & 809 & 2.4 & 0.167 & - \\
\hline Isopentanol & Up to 148 & 831 & 2.2 & 0.141 & - \\
\hline Octane & Up to 126 & 704 & 2.4 & 0.134 & - \\
\hline Engine oil & Up to 160 & 888 & 1.88 & $\sim 0.1$ & - \\
\hline $\begin{array}{l}\left.\text { XCELTHERM }^{(}\right) \\
\text {XT }\end{array}$ & $-55-272$ & 1000 & 1.70 & 0.133 & [4] \\
\hline $\begin{array}{l}\text { XCELTHERM }^{\circledR} \\
\text { XTE }\end{array}$ & $-57-270$ & 968 & 1.63 & 0.135 & [4] \\
\hline $\begin{array}{l}\text { XCELTHERM }^{\circledR} \\
500\end{array}$ & $-60-260$ & 789 & 2.16 & 0.137 & [4] \\
\hline $\begin{array}{l}\text { THERMINOL }{ }^{\circledR} \\
\text { VLT }\end{array}$ & Up to 99 & 744 & 1.95 & 0.112 & [5] \\
\hline $\begin{array}{l}\text { THERMINOL } \\
\text { Lt }\end{array}$ & Up to 181 & 862 & 1.79 & 0.124 & [5] \\
\hline $\begin{array}{l}\text { THERMINOL }^{\circledR} \\
\text { D12 }\end{array}$ & Up to 192 & 759 & 2.10 & 0.109 & [5] \\
\hline $\begin{array}{l}\text { DURATHERM }^{\circledR} \\
\text { XLT-50 }\end{array}$ & -45 to 121 & 820 & 2.10 & 0.137 & {$[6]$} \\
\hline $\begin{array}{l}\text { DURATHERM } \\
\text { HTO }\end{array}$ & Up to 315 & 811 & 1.89 & 0.137 & [6] \\
\hline $\begin{array}{l}\text { DOWTHERM } \\
4000\end{array}$ & $-50-175$ & 1055 & 3.6 & 0.442 & {$[7]$} \\
\hline $\begin{array}{l}\text { DOWTHERM }{ }^{\mathrm{TM}} \\
\text { SR1 }\end{array}$ & $-50-120$ & 1045 & 3.6 & 0.442 & [7] \\
\hline DOWFROST $^{\mathrm{TM}}$ & $-45-120$ & 1033 & 3.8 & 0.434 & [7] \\
\hline UCARTHERM $^{\mathrm{TM}}$ & $-51-121$ & n.a. & n.a. & n.a. & [7] \\
\hline DOWCAL $^{\text {TM }} 100$ & $-50-175$ & 1047 & 3.69 & 0.485 & [7] \\
\hline DOWCAL ${ }^{\mathrm{TM}} \mathrm{N}$ & $-45-120$ & 1026 & 3.88 & 0.456 & [7] \\
\hline
\end{tabular}

During recent years, researches are focused on the potential of using low-cost alternative materials for solid sensible heat storage (e.g., [9-11]). These recycled materials are generally solid industrial by-products or wastes: asbestos containing wastes (ACW), fly ashes, by-products from the salt industry and from the metal industry, wastes from recycling steel process and from copper refining process and dross from the aluminum industry, and municipal wastes (glass and nylon) [9]. The yearly production of these industrial by-products or wastes is sufficiently abundant to be considered as candidates of storage materials [9]. In terms of thermo-physical properties, recycled materials are comparable, sometimes even more performant 
than conventional ones, with high thermal and chemical stability and attractive investment cost $[12,13]$. In most of the cases, they are targeted to high temperature applications such as concentrated solar power (CSP) plants [14, 15] or compressed air energy storage (CAES), as competitors to molten salts. Recently, it is also reported that these recycled wastes could be used as thermal mass materials for low-energy building construction $[12,16]$ or combined with solar cooling systems [17], indicating their promising potential as sensible storage materials for buildings.

Table 2 shows indicative thermos-physical properties of some solid materials used or have the potential to be used in sensible heat storage systems for buildings.

\section{Materials for Cold Storage}

Chilled water is the most common liquid material for cold thermal energy storage (CTES) in buildings. It is usually stored in specially insulated water tank for daily storage (e.g., [18]) or underground for seasonable storage (e.g., [19]), in connection with the HVAC system of buildings. Ice, as the solid state of water, is also used as storage media, to be stored in special ice storage tanks for daily operation (e.g., [20, 21]). In some cases, ice remains solid during charging/or discharging when it exchanges sensible heat with HTFs (usually air) whereas in other cases phase change may occur to produce chilled water [22], indicating that both sensible and latent heat are involved. For seasonal storage of cold energy, ice or snow can be collected in winter and stored in the form of ice/snow ponds (e.g., [23, 24]). During summer seasons, the stored cold energy could be then recovered by circulating air through the ice/snow ponds. It is also reported that pebbles can also be used (in the form of pebbles bed) for seasonal storage of cold energy [25] in tropical areas (Moroccan).

\section{Short Summary}

In summary, the selection of suitable materials with potential for sensible TES in buildings is not an easy task. It is generally application-oriented in which the working temperature range should be firstly considered while other selecting parameters should also be taken into account. The multi-criteria methodology developed by Prof. Ashby [26] associated with Cambridge Engineering Selector (CES) software could be a practical tool. Some case studies were presented in the literature [12, 27] for evaluating materials for sensible TES with the objective of minimized cost.

\section{Sensible TES Technologies for Building Applications}

In this section, various building integrated sensible energy (heat or cold) storage systems or technologies will be introduced. Many of the technologies already have their real applications in buildings while some of them are under development undergoing lab-pilots testing. Each technology will be described in details including 
Table 2 Indicative thermo-physical properties of some solid materials for sensible heat storage in buildings $[8,9]$

\begin{tabular}{|c|c|c|c|c|}
\hline Material & $\begin{array}{l}\text { Temperature } \\
\text { range } \\
\left({ }^{\circ} \mathrm{C}\right)\end{array}$ & $\begin{array}{l}\text { Density } \\
\rho\left(\mathrm{kg} \cdot \mathrm{m}^{-3}\right)\end{array}$ & $\begin{array}{l}\text { Specific heat } \\
C p(\mathrm{~kJ} . \\
\left.\mathrm{Kg}^{-1} \mathrm{~K}^{-1}\right)\end{array}$ & $\begin{array}{l}\text { Thermal conductivity } \\
k\left(\mathrm{~W} \cdot \mathrm{m}^{-1} \mathrm{~K}^{-1}\right) \text { at } \\
20{ }^{\circ} \mathrm{C}\end{array}$ \\
\hline Brick & $20-70$ & 1600 & 0.84 & 1.20 \\
\hline Concrete & $20-70$ & 2240 & 1.13 & $0.9-1.3$ \\
\hline Cement sheet & $20-70$ & 700 & 1.05 & 0.36 \\
\hline $\begin{array}{l}\text { Gypsum } \\
\text { plastering }\end{array}$ & - & 1200 & 0.84 & 0.42 \\
\hline Granite & $20-70$ & 2650 & 0.90 & 2.90 \\
\hline Marble & $20-70$ & 2500 & 0.88 & 2.00 \\
\hline Sandstone & $20-70$ & 2200 & 0.71 & 1.83 \\
\hline Stone, granite & Up to 160 & 2640 & 0.82 & $1.70-3.98$ \\
\hline Stone, sandstone & Up to 160 & 2200 & 0.71 & 1.83 \\
\hline Clay sheet & - & 1900 & 0.84 & 0.85 \\
\hline Asphalt sheet & - & 2300 & 1.70 & 1.20 \\
\hline Cork board & - & 160 & 1.89 & 0.04 \\
\hline Wood & - & 800 & 2.09 & 0.16 \\
\hline Plastic board & - & 1050 & 0.84 & 0.50 \\
\hline Rubber board & - & 1600 & 0.20 & 0.30 \\
\hline PVC board & - & 1379 & 1.00 & 0.16 \\
\hline Asbestos sheet & - & 2500 & 1.05 & 0.16 \\
\hline $\begin{array}{l}\text { Formaldehyde } \\
\text { board }\end{array}$ & - & 30 & 1.67 & 0.03 \\
\hline Thermalite board & - & 753 & 0.84 & 0.19 \\
\hline Fiber board & - & 300 & 1.00 & 0.06 \\
\hline Siporex board & - & 550 & 1.00 & 0.12 \\
\hline $\begin{array}{l}\text { Polyurethane } \\
\text { board }\end{array}$ & - & 30 & 0.84 & 0.03 \\
\hline Light plaster & - & 600 & 1.00 & 0.16 \\
\hline Dense plaster & - & 1300 & 1.00 & 0.50 \\
\hline Aluminum & Up to 160 & 2707 & 0.90 & 204 \\
\hline Aluminum oxide & Up to 160 & 3900 & 0.84 & 30 \\
\hline Aluminum sulfate & Up to 160 & 2710 & 0.75 & - \\
\hline Cast iron & Up to 160 & 7900 & 0.84 & 29.3 \\
\hline Pure iron & Up to 160 & 7900 & 0.45 & 73 \\
\hline Calcium chloride & Up to 160 & 2510 & 0.67 & - \\
\hline Copper & Up to 160 & 8954 & 0.38 & 385 \\
\hline Steel slab & $20-70$ & 7800 & 0.50 & 50 \\
\hline $\mathrm{ACW}$ & $0-1000$ & 3120 & $0.8-1.03$ & $1.4-2.1$ \\
\hline Fly ashes & $25-1100$ & $2600-2962$ & $0.71-1.3$ & $1.2-1.6$ \\
\hline Original $\mathrm{NaCl}$ & $100-200$ & 1384 & 0.74 & 0.33 \\
\hline $\begin{array}{l}\text { Water shaped } \\
\mathrm{NaCl}\end{array}$ & $100-200$ & 2050 & 0.74 & 2.84 \\
\hline Astrakanite & $0-100$ & - & $0.9-1.2$ & - \\
\hline
\end{tabular}


different aspects: basic principle, development status, performance and costs, potential and barriers, today's R\&D activity focus, etc. For the convenience of description, these sensible TES technologies are classified into two categories: one for short-term storage (daily mismatch) while the other for long-term storage (seasonal mismatch).

\section{Short-Term Sensible TES Technologies}

\section{Water Tank}

Water tank is a well established and may be the most widely accepted technology for daily TES in buildings. It plays key roles as TES and redistribution. The power source for the water tank could be variable, the most common case is coupled or integrated with conventional gas/electric boilers (e.g., [28]), air-water heat pumps (e.g., $[29,30])$, or combined heat \& power (CHP) (e.g., [31-35]), as being used in a large number of existing buildings all over the world. Renewable energies could also serve as the power source, including solar energy (flat plate, vacuum tube solar collectors, PV panels, or their hybrid) (e.g., [36-40, 41, 208]), geothermal energy (e.g., [2, 42]), or fuel cells (e.g., [43, 44]). In this case, fossil/electric backup directly integrated or coupled to the water tank is usually a necessary complement. Poly-generations could be another choice (e.g., $[45,46])$.

Both hot water and cold water can be stored at water tanks. Hot water tank usually stores water from about $40{ }^{\circ} \mathrm{C}$ to $80{ }^{\circ} \mathrm{C}$ depending on the heat source and power, mainly for the purposes of space heating and domestic hot water (DHW) production. It should be noted that the stored hot water can also be used for space cooling, usually by running an absorption chiller (e.g., [39, 40, 47-51]) or thermoelectric elements (e.g., [52]) at the downstream of water tank. In cold water tank, chilled water below the room temperature (usually from about $3{ }^{\circ} \mathrm{C}$ to $15^{\circ} \mathrm{C}$ ) is stored, for the purpose of space cooling.

Water tanks could be located either inside or outside the buildings or even underground, with different geometries (vertical/horizontal cylindrical or rectangular) and sizes (from several tens of liters for a single room to a few thousand cubic meters for a district heating and cooling plant). One example of typical hot water storage tank to be combined with solar collectors is shown in Fig. 1. They could be made of a wide variety of materials such as steel, aluminum, or reinforced concrete. By using fiber/plastic composites, expanded polystyrene (EPS) and encasement material, the water tank weight could be one third of that of a compatible storage tank made of steel and is corrosion-free [54]. Generally, they have to be insulated to avoid thermal losses to the ambient, using conventional materials such as glass wool [55], mineral wool, eco cotton-wool [28], polyethylene terephthalate (PET)-fiber fleeces [56], or polystyrene panels [30]. Developing advanced insulation materials having an extra low thermal loss rate $(\lambda=0.01 \mathrm{~W} / \mathrm{m} . \mathrm{K})$ and reasonable thickness for water storage tanks, such as silica aerogel based [57] or vacuum insulation panels [58], is one of today's R\&D activities focuses.

Another R\&D focus is how to maintain the temperature stratification (higher temperature at the top while lower temperature at the bottom) in the water tank 
Fig. 1 Roth's Thermotank Quadroline [53] a

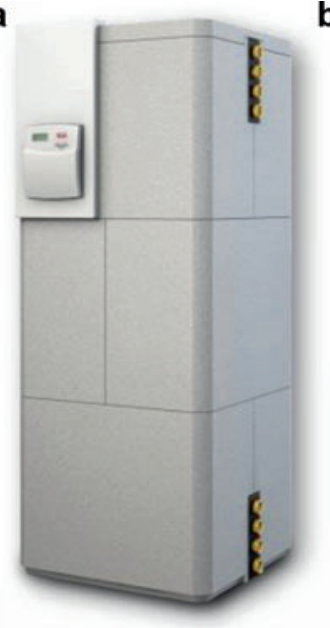

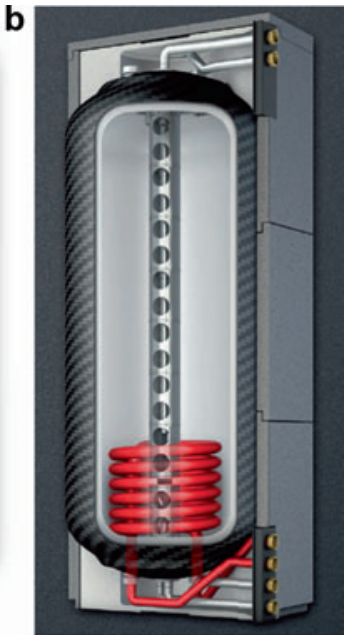

(Fig. 2), a key factor that can effectively improve the performance of the energy storage. Ghaddar [59] found that the energy storage efficiency and the whole system may be augmented by up to $6 \%$ and $20 \%$ by using fully stratified water tank instead of fully mixed one in many solar water heating systems. Various solutions have been proposed to inhibit the turbulence generated from the mixing of the hot and the cold water during charging or discharging. These measures include optimizing the geometrical parameters of the water tank (e.g., tank size; height-to-diameter ratio, etc.) (e.g., [18, 60, 61]), better selecting inlet/outlet positions and shapes (e.g., [62-66]), determining appropriate operating conditions (inlet flow velocity, temperature, cyclic duration, etc.) (e.g., [67-69]), and adding baffle plate or porous mesh at the inlet of the tank (e.g., [70-72]). Recent studies also showed that using partition/stratification plates in the water storage tank could lead to good performance in both energy storage and thermal stratification $[73,74]$. A detailed review on the thermal stratification within the water tank was provided by [73].

\section{Packed Bed}

Packed beds (also known as rock beds or pebble beds) consist of a bed of loosely or structurally packed solid materials through which the HTF can flow. For buildings applications, it is usually used in conjunction with air-based solar collectors, either directly integrated into the solar collector (e.g., $[55,75,76])$ or standing independently as a tank and connected to the solar collector via pipes or ducts (e.g., [77, 78]). During the charging phase, heated air from the solar collector passes the pebbles bed from the top down to the bottom to release the heat. During the heat-discharging phase, the air from room enters from the bottom to the top of the bed to absorb the stored heat and the heated air is then delivered into the building.

Packed beds are generally considered as the most suitable energy storage unit for air-based solar systems for buildings (e.g., Fig. 3) owning to the abundant and lowcost solid storage materials available and the efficient heat transfer through the direct 
a

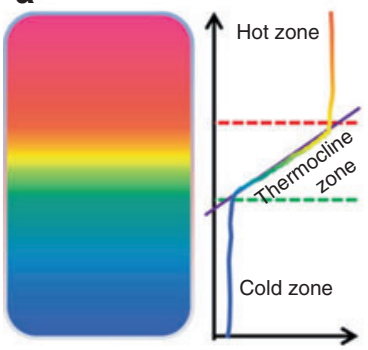

b

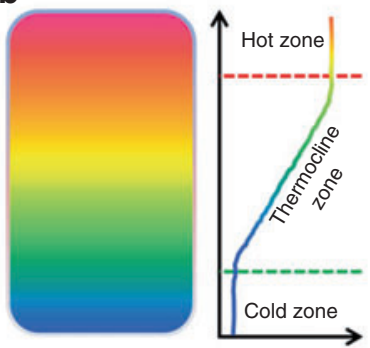

c
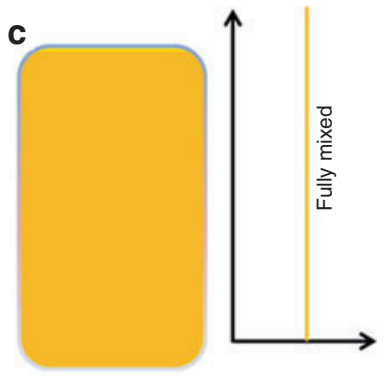

Fig. 2 Differing degrees of stratification within a storage tank with the same amount of stored heat: (a) highly stratified, (b) moderately stratified, and (c) showing fully mixed, unstratified storage [202]

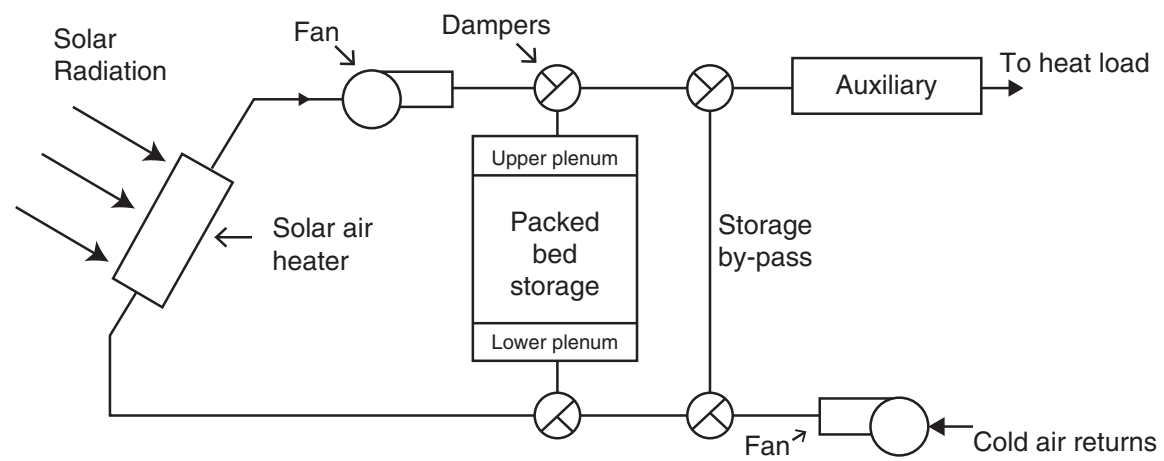

Fig. 3 Schematic of a packed bed energy storage combined with air-based solar system for buildings [80]

contact between air and the solid particles. Michelson and Shitzer [79] studied a solar air heating system designed for a floor of $120 \mathrm{~m}^{2}$ offices in Israel and reported that adding a rock bed storage could improve the system's performance. Otherwise, the increased solar collector area is needed. Singh et al. [78] reported that the heat retrieval efficiency of a packed bed could reach about $75-77 \%$, better than that of PCM-based storage system (66.7-72\%).

Despite a variety of storage materials available, the shape and size of the packing materials and void fraction are key factors that determine the thermal performance and the pressure drop of the storage unit [80]. Sorour [81] investigated small size (several dozen liters) pebbles bed storage units used in many short-term applications and reported that lower flow-rates of HTF with intermediate particle diameter of pebbles are advantageous to achieve high efficiencies of the storage unit. Ammar and Ghoneim [82] reported that particles with smaller diameter, i.e., with higher values of interfacial surface area per unit volume cause a large degree of thermal stratification in the bed. Nonetheless, Sagara and Nakahara [83] suggested that a trade-off has to be made between the thermal performance and 
pressure drop in designing packed bed storage unit. For example, a large size material like bricks or concrete blocks may have poorer thermal performance, but the required power supply to run the fans is also small. An economic evaluation might become a decisive factor for the design.

Besides conventional concepts for packed beds storage unit, some new configurations were also proposed to intensify the heat transfer. Audi [84] proposed to use a storage bin with trays to carry the rocks instead of randomly packed rocks. Crandall and Thacher [85] proposed the arrangement of segmented/cascade storage tank system instead of a single tank. Other researchers also proposed to use combined storage systems such as coupled rock bed and water storage unit [86] or combined rock bed - solar pond storage system [87]. A detailed review on packed bed solar energy storage systems was presented by [80].

\section{Thermal Mass}

Thermal mass of a building is natural thermal storage media. If controlled or managed appropriately, the use of heavyweight construction materials has various advantages owning to their high TES capacities including (1) dampen the wide range temperature fluctuation from the outdoor [88]; (2) reduce the peak heating or cooling power demands [89]; (3) maintain the indoor thermal comfort [102]; (4) reduce lifecycle $\mathrm{CO}_{2}$ emissions [91]; and (5) resist to structural damage by severe storms [92].

Akbari et al. $[93,94]$ reported that the heat storage capacity of the massive structural materials (both external and internal walls) in buildings is affected by the convective heat transfer coefficients of air profile. Yam et al. [95] further developed understanding of the thermal mass effect and found that there is an optimal amount of thermal mass to be used in building passive design as further increase of thermal mass would not increase storage effect. Ma and Wang [96] also found different optimal thicknesses of interior planar thermal mass of various materials for reaching a maximum value of the heat storage capacity. As a result for different buildings, this optimal amount of thermal mass should be determined carefully.

Recent R\&D focus on the thermal mass topic lies on the development of optimal operation strategies for building thermal processes, taking the TES by thermal mass factor into account. These thermal mass include the building structure (external and internal walls) [209], earths [92], internal furniture and contents [97, 98], stored products in warehouses [201], or water-filled containers [99]. Some examples are shown in Fig. 4. For commercial buildings, Henze et al. [100] studied the impacts of adaptive comfort criteria and heat waves on optimal building thermal mass control. A model-based demand-limiting control of building thermal mass was developed by Lee and Braun [101]. Recently, Li and Malkawi [102] developed a multi-objective optimization based model predictive control framework that takes both energy cost and thermal comfort into consideration simultaneously. For residential buildings, Le Dréau and Heiselberg [103] found that the thermal mass storage potential depends largely on the insulation level thus the control strategy should be designed differently to make use of the flexibility potential without violating the comfort. 
a

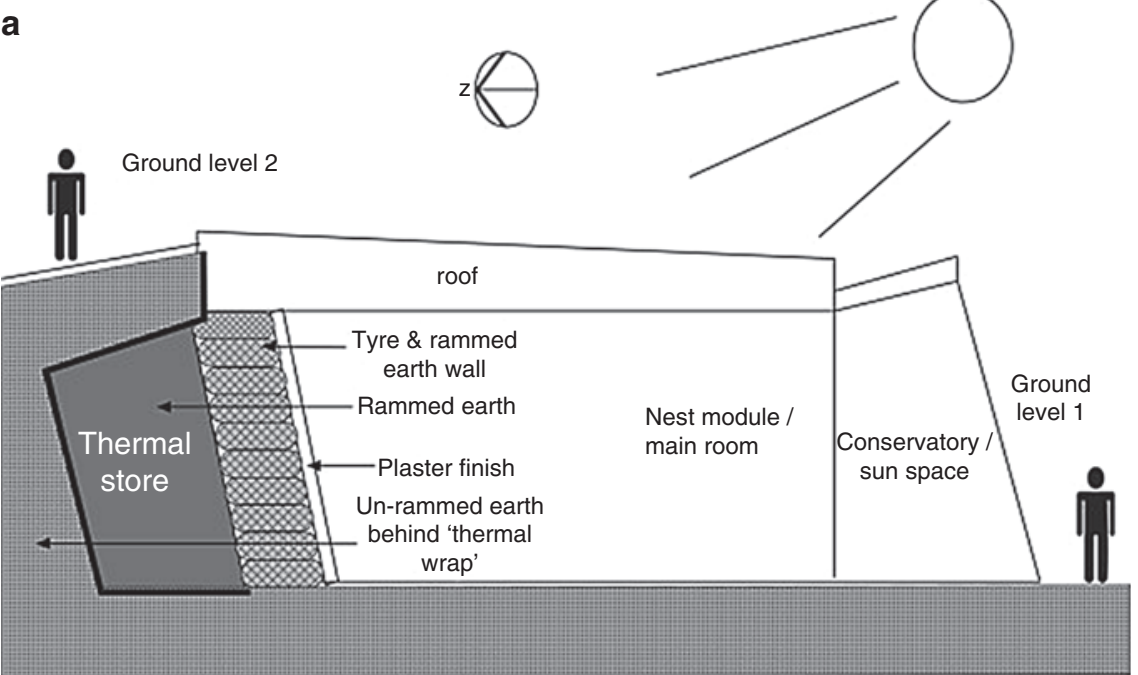

Dimensions are not to scale

b

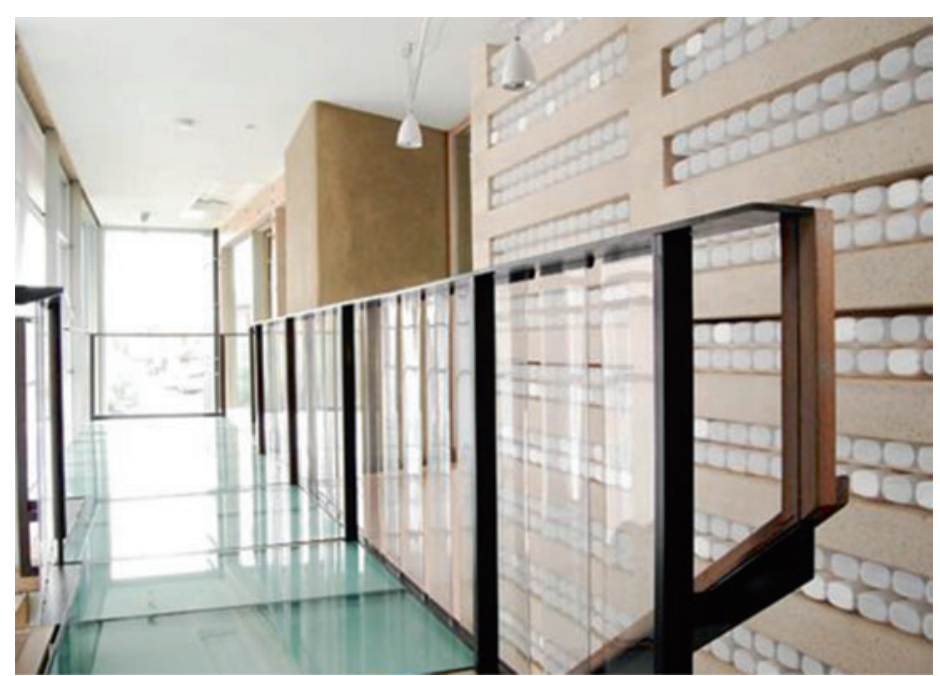

Fig. 4 Thermal mass for TES in buildings. (a) Section of Brighton Earthship [92]; (b) water filled containers in Marsh House Two [99]

One future direction of thermal mass storage is the development of hybrid adaptable thermal energy storage approach that usually used PCMs integratedlightweight building construction materials [104] or PCMs integrated-internal furniture [105] to improve the thermal comfort. 


\section{Thermally Activated Building Systems (TABS)}

Different from the thermal mass, thermally activated building systems involve building surfaces or building structures with water pipes or air ducts embedded. Water or air is used as HTF while the building mass is used as storage media to buffer the room temperature fluctuation by storing or releasing the heat from the thermal mass. TABS is a really ancient concept that can be tracked back to Roman hypocaust, Korea Ondol, and Chinese Kang, using oven, boiler, or stove as the heat source. An historical review on TABS research was presented by [106]. These heating and storage systems in buildings developed by different countries share similar principles and are now still widely used with some conceptual developments. Owing to the advantages such as high thermal inertia, big heat transfer surfaces, and radiative nature, TABS is still applicable in modern buildings.

Hypocaust is a building construction concept originated during ancient Roman in which the hot gases from the furnace are guided to pass through floors (square pillars) and cavity walls and to warm the rooms of buildings. The emissions are then discharged through holes in the roof. In this case, the building structure serves as thermal mass for the sensible heat storage. Bansal [107] analyzed four hypocaust constructions in modern Europe (School of Tournai, Belgium; Meteolabor Laboratories, Switzerland; Sogeco Office Building, Italy and Schopfloch Kindergarten, Germany) and concluded that it is a good alternative even in modern concept of building heating because the heat losses from building walls/floors are first reduced.

In China, the Chinese Kang is a device widely used in cold regions in Northern China by more than 175 million people [109]. It is actually a multi-functional rural domestic system that serves cooking, space heating, bed warming, thermal storage, and natural ventilation purposes. A typical Chinese Kang consists of a stove, a Kang body (similar to a bed), a chimney, and airflow paths for the smokes. The Kang body/ plate is heated by the hot smoke flow during cooking time. The thermal energy stored in the thermal mass material of Kang bed (concrete, earth, or stone) can maintain a heating period of several hours or more for the room by convection and radiation [109].

The commonly used Kangs today include the traditional grounded Kang and new elevated Kang. The major difference is that the former is directly built into the floor while the latter is suspended from the floor. The improvements achieved by the elevated Kang include the increased heat utilization of smoke, improved temperature uniformity of the Kang bed, and higher controllability and insulation level [109]. The design of thermal storage by the Kang body is a key factor that affects the indoor thermal comfort level and the biomass energy saving potential. Zhuang et al. [108] had developed an elaborate thermal and airflow model and investigated thermal storage characteristics of a Chinese Kang. A design guide was also proposed to determine the thickness of a Kang plate (quantity of thermal mass) and firing distribution. Recent developments of Chinese Kang concern the combination of solar energy and biomass energy for cooking as the heat source.

Similar architecture also exists in Korea, named as Ondol. Instead of a Kang bed, it is the whole floor of the building that will be heated by the hot smoke from a firebox or a stove (Fig. 5). As a result, it is also called radiated floor of Korea style. 


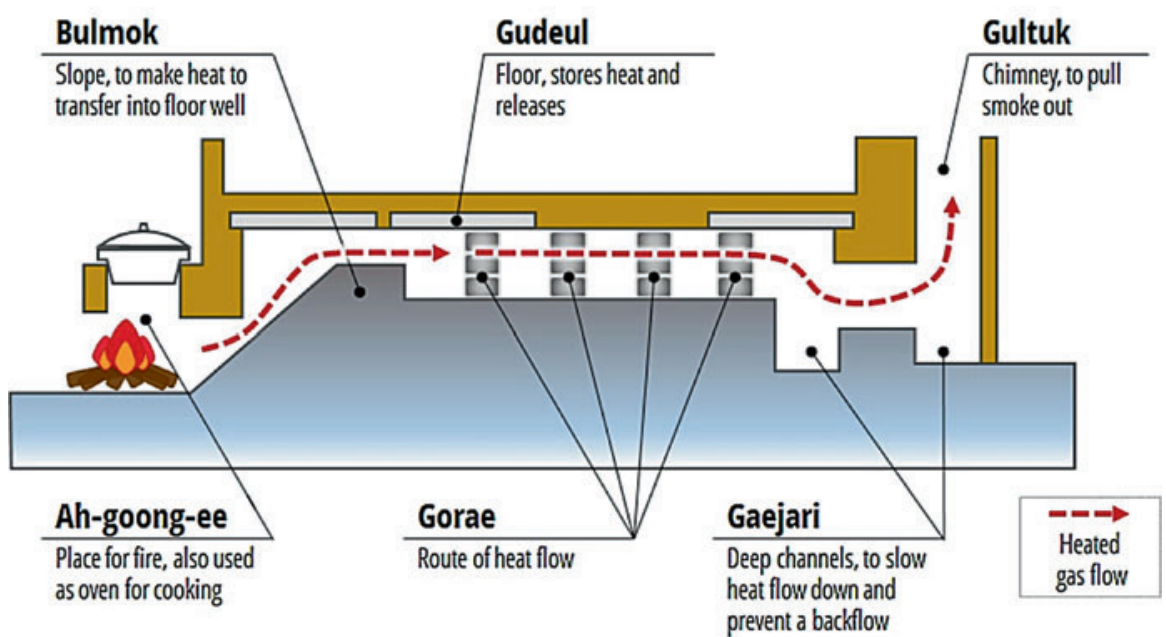

Fig. 5 Schematic view of Korean under-floor heating system Ondol [111]. Similar principles may also be found in other contraries such as ancient Romaine's Hypocaust or Chinese Kang

The heated floor, supported by stone piers or baffles to distribute the smoke, is covered by stone slabs, concreate slabs, clay, or sand layer [110] and an impervious layer such as oiled paper. The improved modern floor/ceiling technology in general involves light-weight TABS placed above the floor structure/at the lower surface of ceilings. It is commonly assumed that the radiant floor/ceiling only exchanges heat with the internal air for heating or cooling of the room while the external layers are well insulated.

Modern concepts similar as Hypocaust are also developed in recent years, including hollow core slabs, concrete core, and pipe-embedded building envelope, as shown in Fig. 6. They are technically prefabricated heavy-weight building walls or slabs with water pipes or air ducts embedded in the slab core.

Recent R\&D focus of TABS includes several directions. Firstly, adding PCMs in the building mass is an effective method to increase the heat storage capacity. Some examples include the use of PCMs as thermal storage material for the Ondol system [110]; prefabricated concrete slab with encapsulated PCMs [114]; and PCM-concrete mixture layers $[115,116]$. The second direction involves the coupling of TABS with low grade energy sources, owing to the efficient heat transfer between HTF and room air even with small temperature gradient. The investigated low-grade energy sources include solar air collectors [117, 118], solar-collected walls [119], buildingintegrated photovoltaic-thermal (BIPV/T) system [120-122], ground source [123, $124,205]$, and natural wind $[125,126]$. Finally, the control strategies for TABS should be carefully determined, which directly affect the comfort conditions and energy saving potential [127]. Supply temperature control with heating and cooling curves is common for most TABS. More advanced controls use heating curves as the base of its control for the determination of the energy to be supplied and the periods 

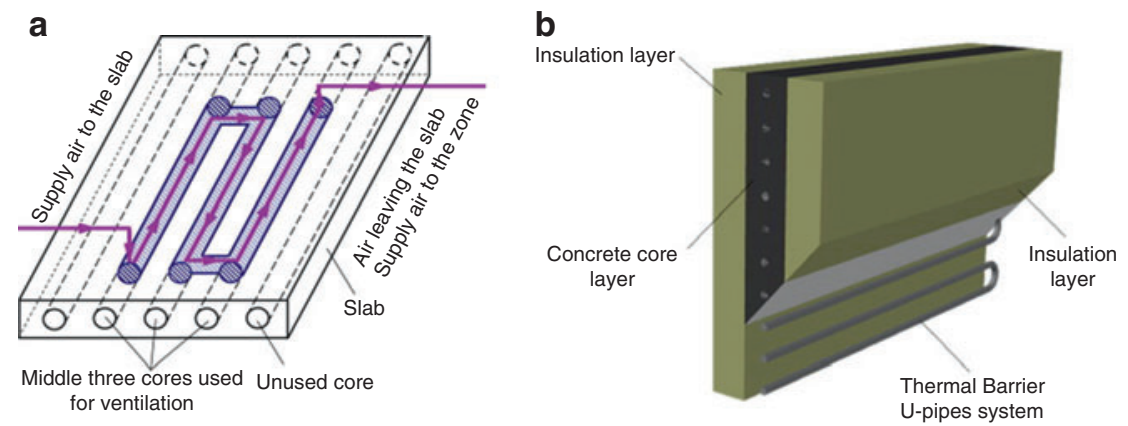

C

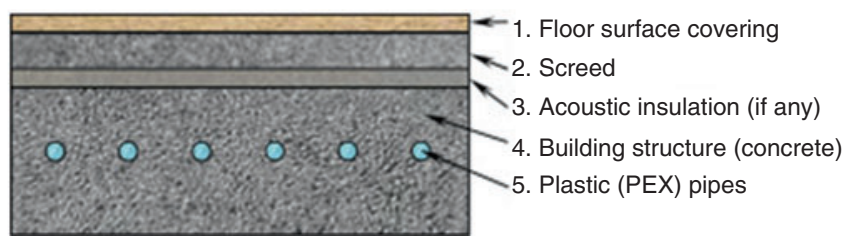

Fig. 6 Different types of prefabricated TABS. (a) hollow core slab [206]; (b) pipe-embedded building envelope [112]; (c) concrete core [113]

of activation. Detailed information on the simulation and control strategies of TABS is provided in the review paper by Romani et al. [127].

\section{Solar Walls}

Solar walls, also named as Trombe walls, usually refer to the building envelope walls which are specially designed to absorb solar rays and store thermal energy, so as to reduce a building's energy consumption. If properly installed, a solar wall could be an important green architectural feature that reduces a building's energy consumption up to $30 \%$ [128].

The basic principle of a classic or standard solar (Trombe) wall can be tracked back to the Gangway vernacular architecture of the Persian Gulf [129] and was again popularized in modern buildings by a French engineer Felix Trombe in the late 1950s [130]. It uses high heat storage capacity materials (e.g., concrete, brick, stones, etc.) as the external wall of a building, which is covered by an exterior glazing with an air space of several centimeters between both components (Fig. 7). The black-painted surface of the wall absorbs diffused and direct solar radiation during the day and transfers the heat to the heavy thermal mass of the wall by conduction. The stored heat could be released gradually when needed through radiation and convection. Air flow in the gas produced by natural or forced convection usually enhances the heat transfer and improves the thermal comfort of the building.

Standard solar wall can be modified into different configurations depending on different purposes and environment conditions. The conceptual evolution could involve natural ventilated or mechanically ventilated [132], vented or unvented 
a

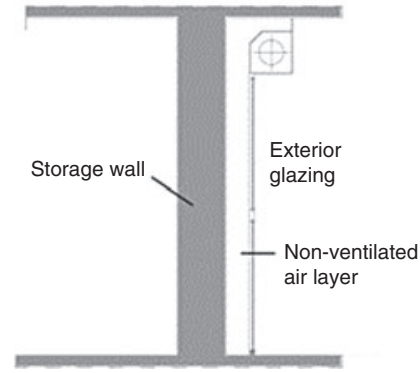

b

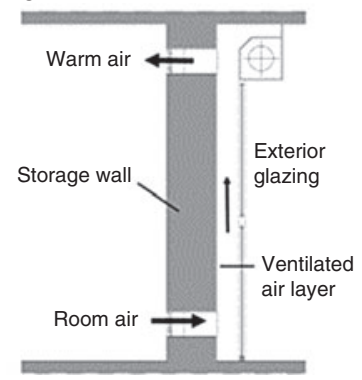

C

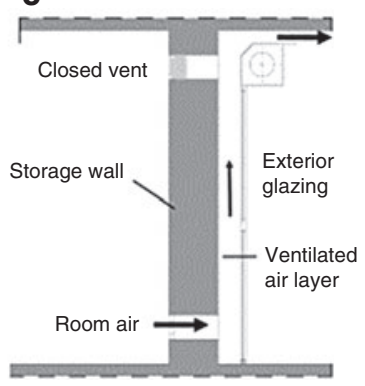

Fig. 7 Various configurations of a solar wall: (a) without ventilation; (b) winter mode with air thermo-circulation; (c) summer mode with cross ventilation [131]

[133], south faced or angled [134], light or dark colored [135, 207], external or internal insulated [136-139; etc.], pure air circulated in the air gap or with fluidized particles added [140].

One development trend is the solar wall having several different layers, also called as composite Trombe wall. Besides the thermal mass layer (e.g., concrete), the combination could include a water layer [141], another concrete layer with forced air ventilation between two layers [142], PCM plasterboards or bricks [143-145] (Fig. 8a), PCM layer with delta winglet vortex generators [110], or coupled layer of PCM and transparent insulation material (silica aerogels) [146]. The main purpose is to increase the heat storage capacity while reduce the thermal losses. Another innovative development is the PV-Trompe wall (Fig. 8b), in which the front side of the glazing is composed of PV panels [147-149]. The use of PV panels instead of glazing would unfortunately reduce the solar heat gain. However, the cooling of PV panels will increase its efficiency in electricity generation. This conception is also referred to as BIPV/T systems.

Further studies in terms of heat storage are suggested on the determination of the optimal thickness of various materials, such as stone, brick, adobe, concrete, etc., for different climate regions [130]. The coupling with other renewable heat sources is also an issue that needs further efforts.

\section{Long-Term Sensible TES Technologies}

Sensible TES technologies can not only be used for short-term (daily) storage in buildings but also for a longer period, i.e., more than several months for interseasonal storage. The main purpose is to store the excessive heat in summer season for supplementing the heating demands during winter, or vice-versa, to store excessive cold in winter for the space cooling during next summer. In this regard, the heat source for seasonal TES is in general the solar energy while the cold source is usually the ice or snow produced in nature due to cold weather. The key issue is then how to reduce the thermal losses during the long storage period, i.e., to maintain the 
Fig. 8. Hybrid solar wall: (a) composite Trombe wall with PCM layers [145]; (b) combined PV-Trombe wall [150]
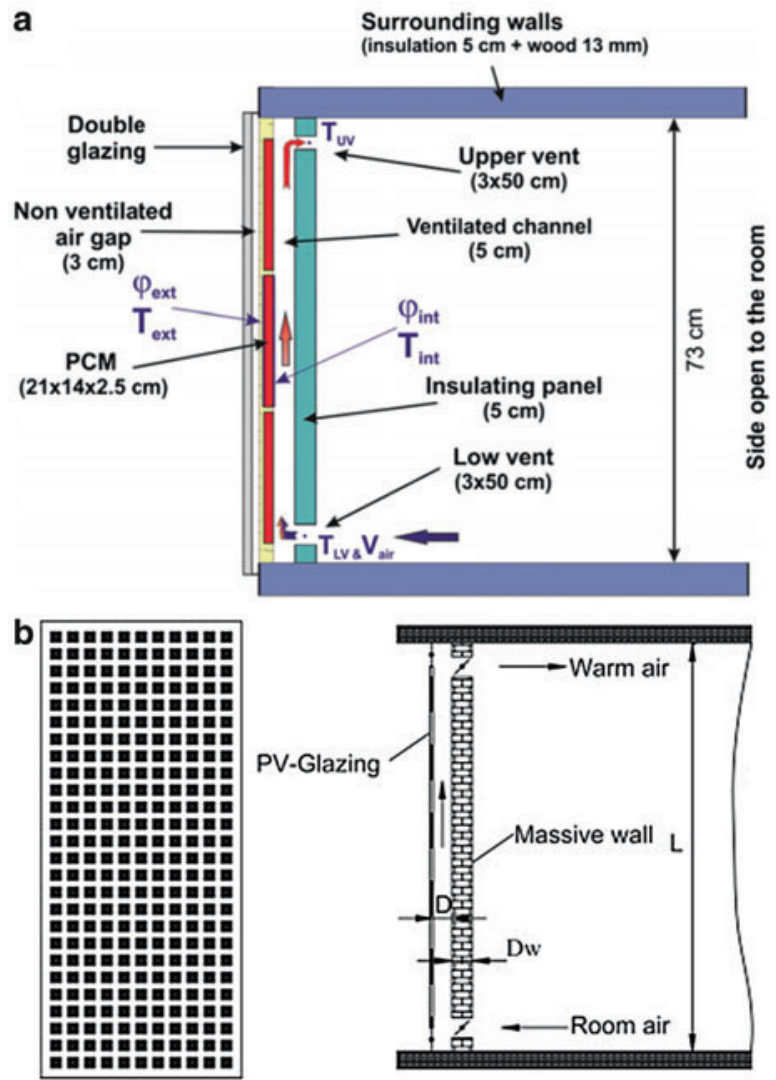

temperature of the sensible storage materials. Otherwise, these technologies will have low energy efficiency thus not be profitable. Since increasing the storage size reduces the loss-to-capacity ratio [151], the development of seasonal TES technologies has been aimed at large-scale district heating and cooling plants instead of single house or apartment.

Generally speaking, there are different ways of sensible seasonal TES. The most common technologies are: water (hot or chilled) tank TES, aquifer TES, borehole TES, and water-gravel TES, as shown in Fig. 9. Among them, the first three use liquid (water) as storage material, the last one (borehole) belongs to the type of sensible solid storage, while water-gravel TES is a combination of liquid and solid storage.

\section{Water Tank}

Water tanks still have the widest range of utilization possibilities for seasonal TES. They are usually made of stainless steel or reinforced concrete with insulations at least at the top of the tank and on the vertical walls [153, 154], partially or totally buried underground $[155,156]$ or outside of a building [157]. Both hot water and 

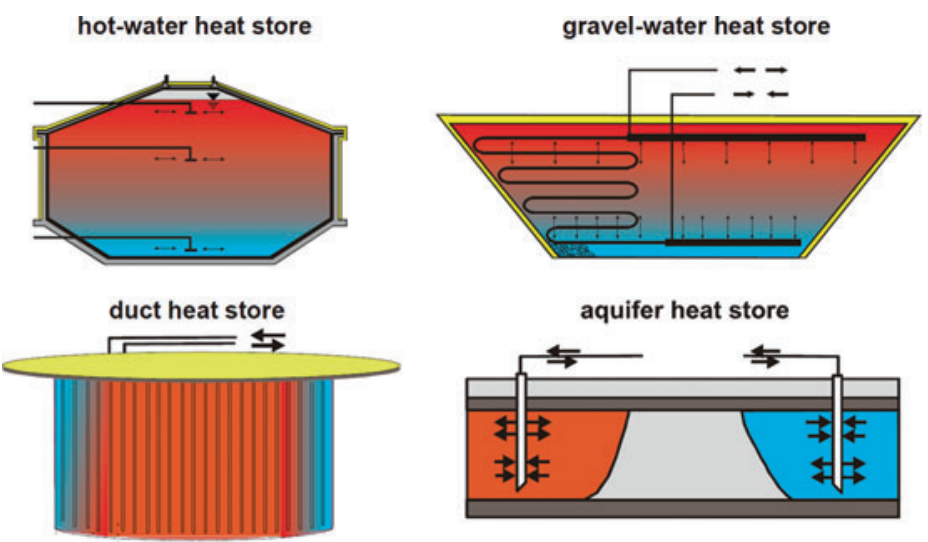

Fig. 9 Different types of sensible seasonal TES [152]

chilled water [19, 158] may be stored in the tank, for the purpose of heating or cooling in the next season. Some demonstration projects for buildings with available details on seasonal water storage tanks are presented in Table 3.

Maintaining the temperature stratification inside the water tank is again a key issue for the storage system efficiency. In addition to measures introduced in 4.1.1, multiple charging/discharging [152] was also proposed instead of conventional two levels for charging and discharging (on the top and at the bottom). More precisely, a third charge/discharge device was introduced at variable height in the middle of the water tank, permitting simultaneous charging and discharging at different temperature levels without disturbing much the temperature stratification.

Another research of interest in water tank seasonal TES lies in the insulation materials and methods so as to reduce the heat losses. Some efforts on this point can also be found in Table 3 and in Fig. 10, in connection with the water tightness issue and vapor leakage problem. An optimization method has also been proposed by [160] for determining the optimal amount and distribution of thermal insulation on the water storage tanks to reduce heat losses and improve the cost-effectiveness. A life-cycle assessment of a European apartment building using water tank seasonal TES is performed by [161].

\section{Gravel-Water}

The gravel-water seasonal TES concept is similar as the water tank TES but both water and rock/gravel are used as storage mediums. The pit/tank is usually buried underground with insulations on the top and on the side walls so as to reduce thermal losses, as shown in Fig. 11. This type of storage is also named as man-made or artificial aquifer [169]. Pipes are usually installed in different layers of the store for the circulation of HTF to release or absorb heat. Since the gravel-water mixture has lower specific heat than pure water, the volume of the whole basin should be approximately 50\% larger compared to water tank TES to obtain the same storage capacity [169]. On the contrary, the lower costs of the envelop structure and storage 


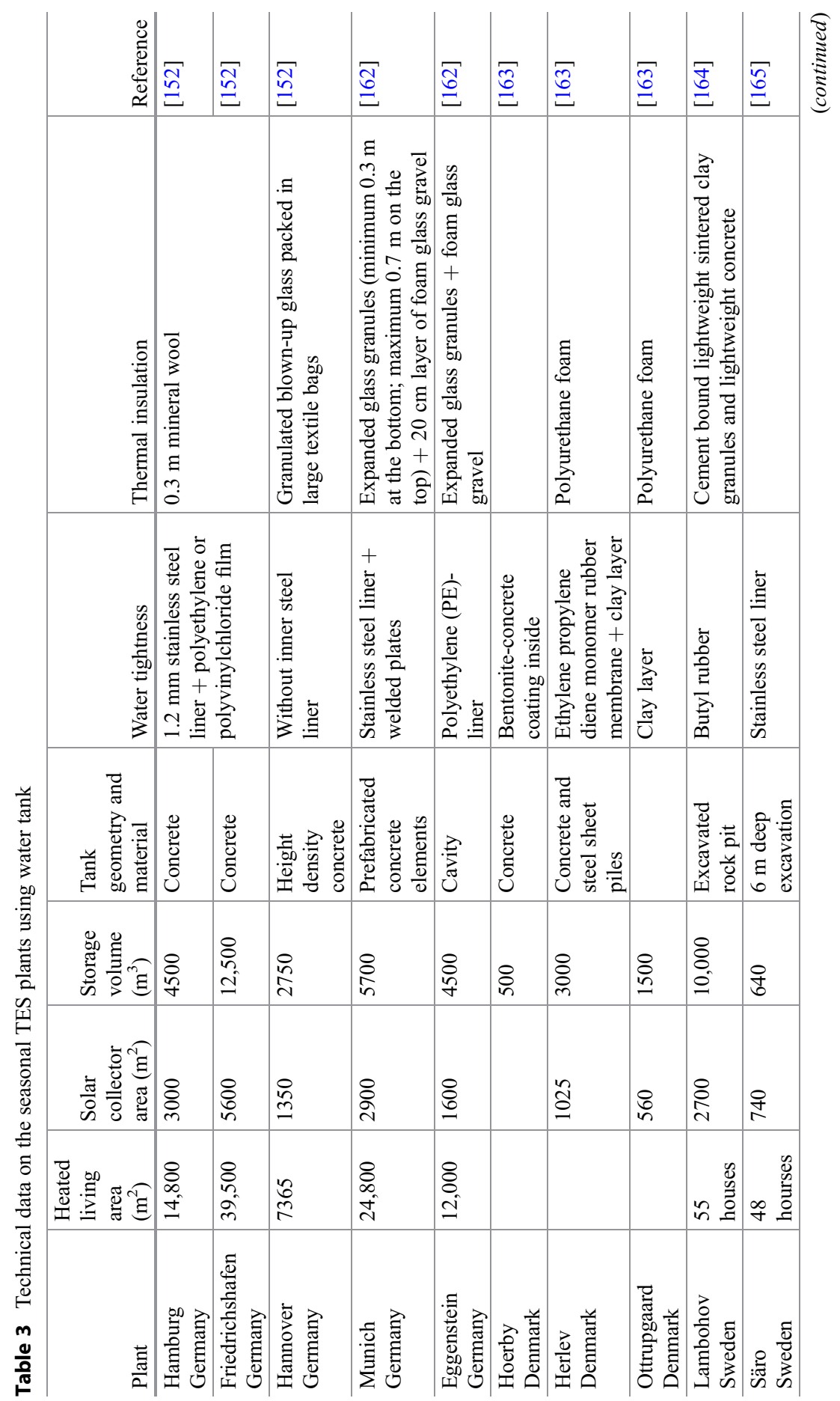




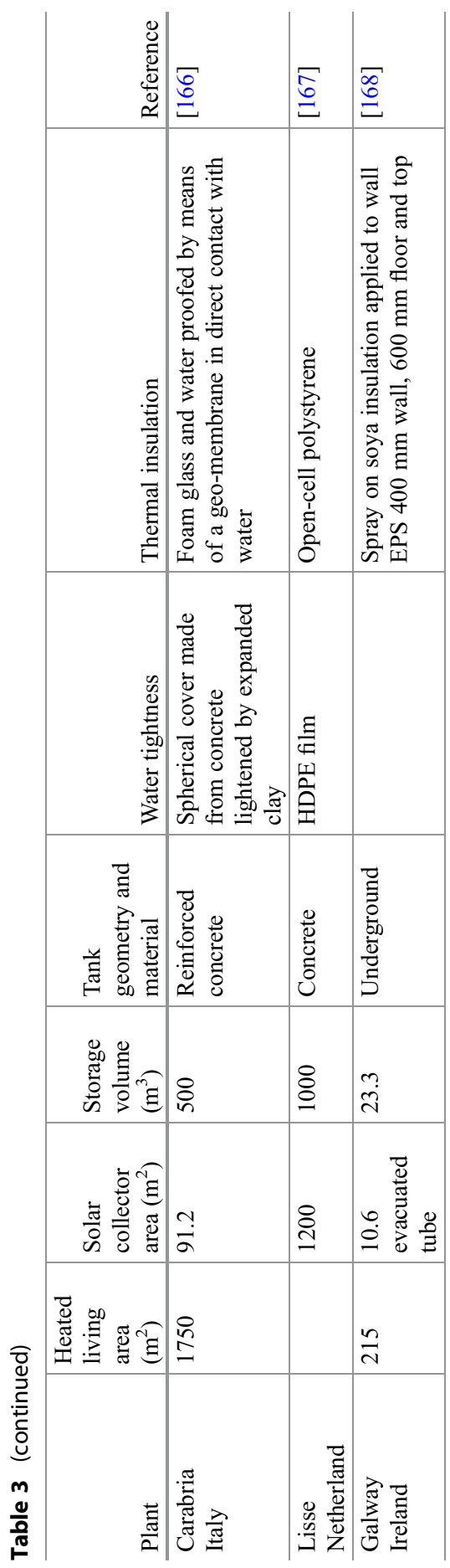



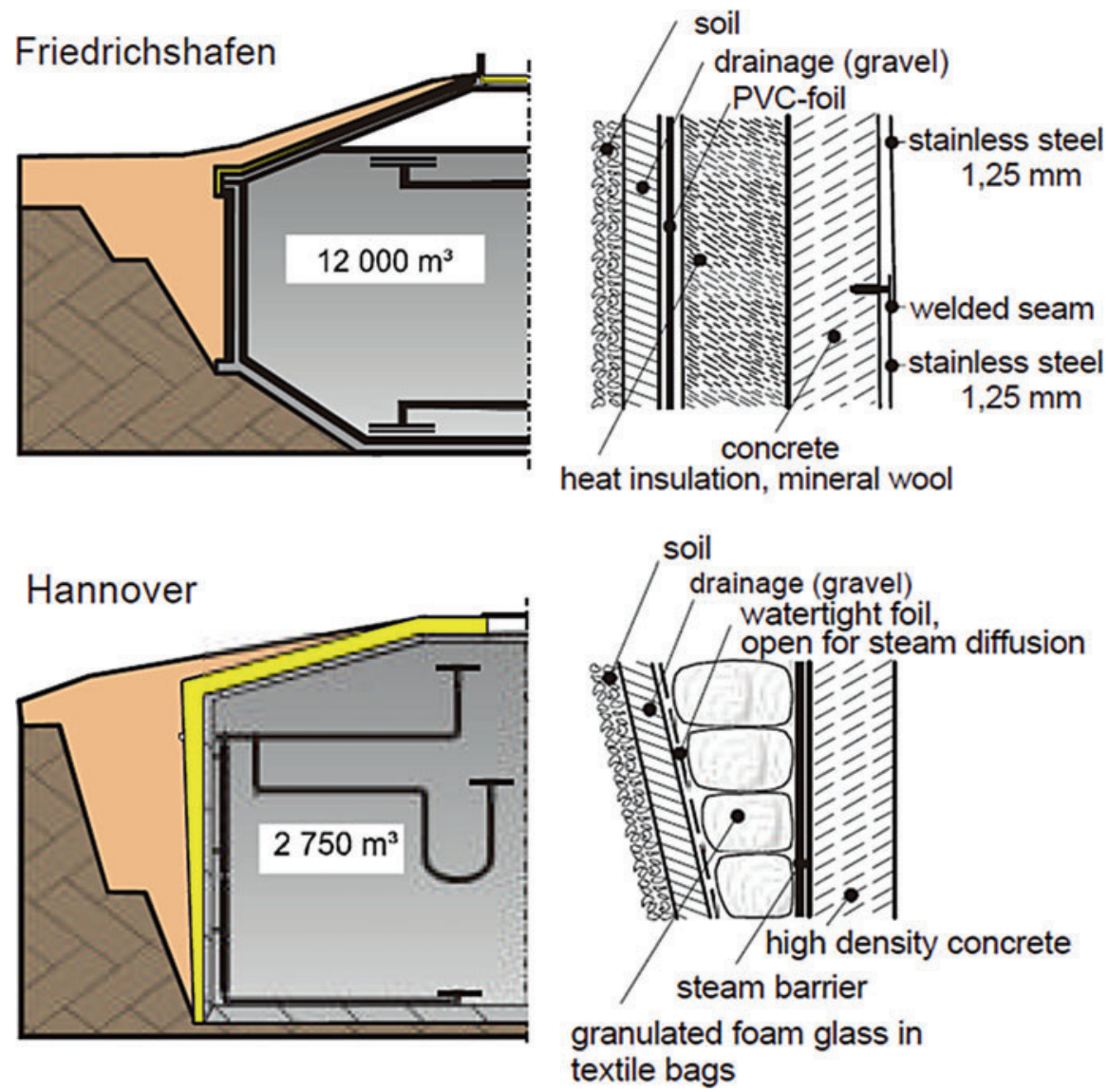

Fig. 10 Insulating techniques for water tank TES systems in Friedrichshafen (left) and Hannover (right) [159]

medium (rock, gravel, sand, etc.) make the gravel-water TES much cheaper. As a result, it also finds its place in for large-scale applications in district heating/cooling plants. Table 4 presents some key parameters of the gravel-water seasonal TES systems realized in Europe.

\section{Aquifer}

An aquifer is a geological formation that contains groundwater and permits significant amounts of water to move through it (Bear 1979). Different from the artificial water tank seasonal TES, aquifer TES relies on the natural aquifer layer, avoiding expensive investments of underground excavation and the construction. It was considered as a "promising cost-effective option" for seasonal storage [171].

In an aquifer TES system, the groundwater saturation zone is used for heat storage purposes. It usually consists of at least two thermal wells drilled into the aquifer - 
Fig. 11 Construction of the gravel-water TES in Steinfurt, Germany [159]

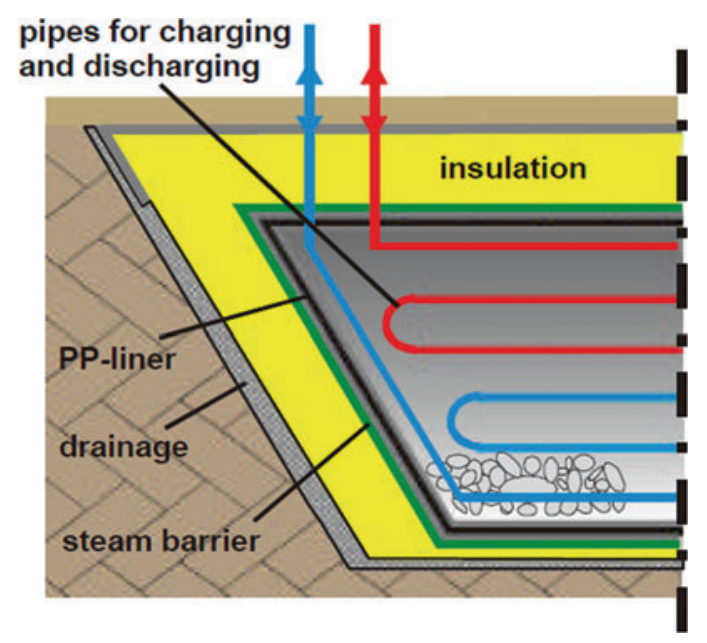

one is called the hot well and the other the cold well. During summer when space cooling is needed, cold water is extracted from the cold well by pumps, heated by the chosen heat source and rejected into the warm well. The circulation is reversed during winter when heating is required, i.e., hot water is extracted from the warm well, cooled and re-injected into the cold well. Due to the large site requirements, aquifer TES technology is more suitable for large scale district heating and cooling plants rather than single family houses or apartments with small loads.

For aquifer TES, geological conditions at the site are the decisive factors. Some expected features include: high ground porosity, medium to high hydraulic transmission rate around the boreholes, minimum ground water flow through the reservoir, chemical stable for the interactions between ground water and the matrix, etc. Moreover, a good knowledge of the mineralogy, geochemistry, and microbiology in the underground is necessary to prevent damage to the system caused by wellclogging, scaling, etc. $[152,173]$. Table 5 presents some key parameters of the aquifer TES systems realized in Germany.

One of the research focuses lies in the influence of groundwater on the efficiency of aquifer TES. Nagano et al. [175] found that large-scale natural convection could occur when high-temperature water is injected into the warm well, which will influence the forced horizontal flow in the saturated porous medium. Zhou et al. [176] numerically studied the influences of the direction and velocity of groundwater on the underground temperature field. They concluded that the groundwater horizontal downstream is favorable to improve the efficiency of combined heat pump and aquifer storage system. Therefore, rational arrangement of well groups should be further considered in the future to achieve a more advantageous effect of groundwater horizontal downstream in practical engineering. Nevertheless, Yapparova et al. [177] found that ground water does not affect the storage efficiency significantly when double concrete walls are provided as thermal insulator. 


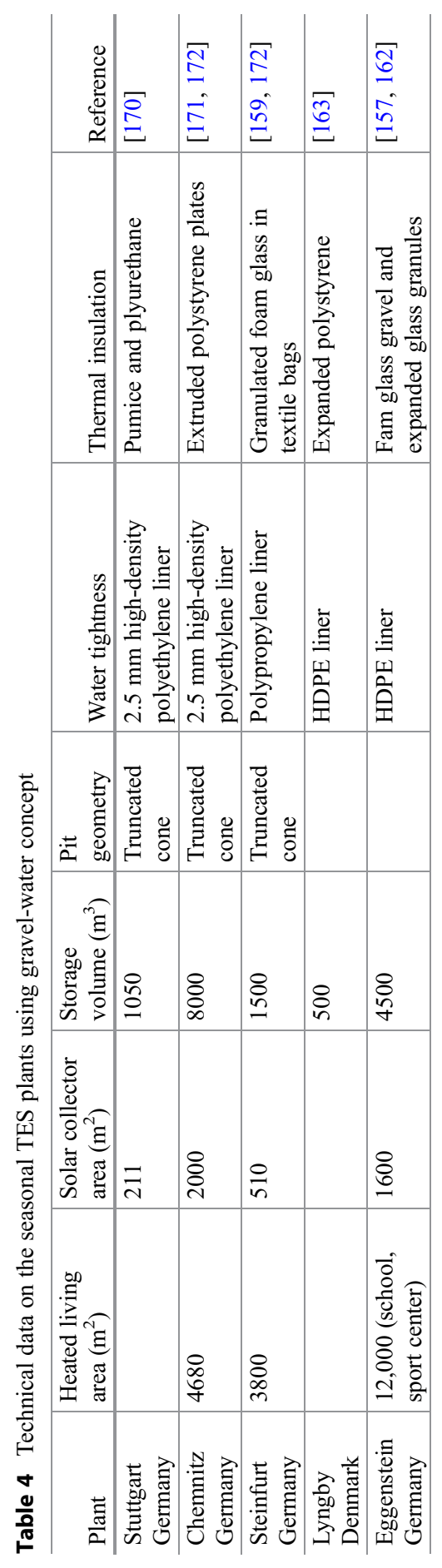




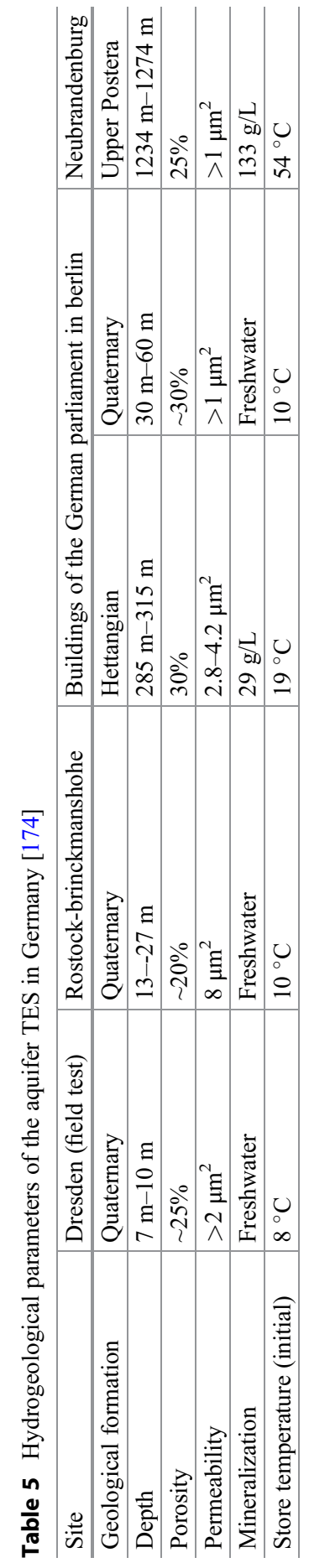


Another research hotspot is on the thermal interference between hot and cold wells in an aquifer or in a number of aquifers in an area on the storage efficiency. Kim et al. [178] numerically found that thermal interference grows as the borehole distance decreases, as the hydraulic conductivity increases, and as the pumping/ injection rate increases. Yapparova et al. [177] reported that storage efficiency increases with the distance between injection and production wells and decreases with increasing injection temperature. Meanwhile, Bakr et al. [179] investigated 19 aquifer TES systems with a total of 76 functioning wells installed in an area of $3.8 \mathrm{~km}^{2}$ in the Netherlands. They reported that interference among individual wells of an aquifer TES system and wells of other systems may have a positive impact on the efficiency of a well/system since it can help in trapping energy (cold or warm) within the capture zone of all operating aquifer TES systems. Sommer et al. [180] further developed an optimization method for determining the optimal well distances/spatial pattern of large-scale aquifer TES, so as to avoid negative thermal interference and to improve the efficiency of the storage system. A recent numerical study [181] revealed the negative thermal interference caused by the premature thermal breakthrough when the thermal front (generated by the thermal injection) reaches the production well. They also found that permeability of the confining rocks, well spacing, and injection temperature are important parameters which influence transient heat transport in the subsurface porous media. It should be noted that the researches on this topic usually use numerical simulation methods, while field experimental measurements are still rare.

The most promising direction for the future development of aquifer TES is the combination with other heat/cold sources/equipment. In essence, heat pump is usually combined with the aquifer TES in order to reach higher heat source temperature and maintain the storage water at a relatively lower temperature, as shown in Fig. 12. Paksoy et al. [203] found a 60\% increase in COP of the combined heat pump and aquifer TES system, when compared to that of a conventional heat pump using ambient air. Ghaebi et al. [182] revealed that the combination of the aquifer TES with the heat pump, to meet both cooling and heating needs of the complex, is an efficient way for building applications. Hill and DeHouche [183] studied the employment of aquifer TES in combination with a commercial water to air heat pump in Afghanistan. They predicted that the annum fuel saving could reach $£ 335,000$ with a payback period of less than 2 years. The application of the concept for heating and cooling in buildings is reported, such as for a hospital in Belgium [184]; an office building in Scarborough, Canada [185]; residential and commercial buildings in Rastatt, Germany, with a storage volume of $23,000 \mathrm{~m}^{3}$ [186]; and multi-family houses in Rostock, Germany, with a storage volume of $20,000 \mathrm{~m}^{3}$ [152]. More details on the heat pump coupling may be found in the review paper [187]. Recently, Xiao et al. [188] investigated the feasibility of the combination of an aquifer TES and the cooling tower of a seasonally running thermal plant. They found that the aquifer TES system could be optimized by locating the cool water supply well upstream of the storage well. 


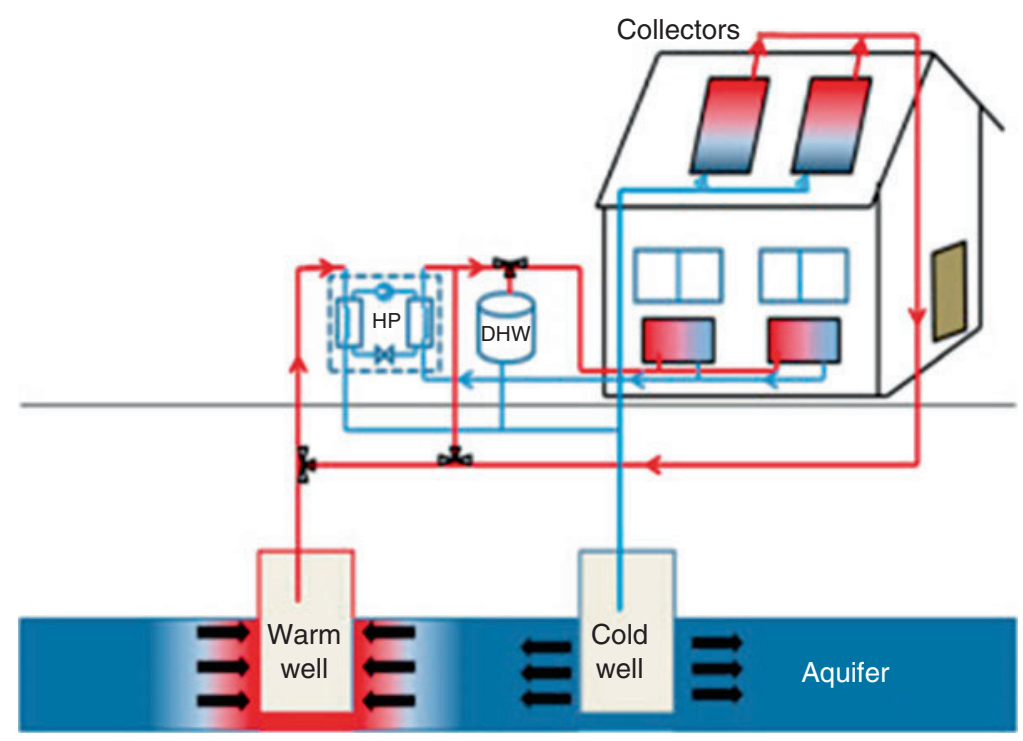

Fig. 12 Aquifer TES combination with a heat pump and solar thermal collectors [187]

\section{Borehole}

Borehole TES uses the ground (rock, sand, soil, etc.) itself as heat storage material, which usually comprises vertically or horizontally drilled boreholes in the ground. It is also called as ground/soil storage or duct heat storage in the literature. Tubes are filled in boreholes (also called borehole heat exchangers) through which the HTFs (usually water or glycol if necessary) circulate to release into or absorb heat from the ground. Different types of borehole heat exchangers are used, such as single U-pipe, concentric-pipe, or double U-pipe, as shown in Fig. 13. The top cover of the borehole system should be insulated to reduce heat losses while there is no specific boundaries underground [189]. Due to the small temperature difference between the ground and the HTF for borehole TES systems, the combination with heat pumps is usually recommended to improve the efficiency of the whole system [187].

One of the important issues for borehole TES systems is the control of heat transfer underground: the heat exchange between the HTF inside the tube and the surrounding ground should be enhanced while the heat conduction away from the reservoir (thermal losses) should be reduced. The influencing factors could include the thermal properties of the materials, the arrangement/configuration of tubes, and the geochemical conditions of the location. Some favorable features for a successful borehole TES are rock/soil with high specific heat, medium thermal conductivity, good contact between the tubes and the surrounding soil and favorable groundwater, etc. Lanini et al. [189] also proposed some design guidelines including the definition of spatial distribution by a cylindrical volume with a diameter twice its height, the depth limitation of borehole at $100 \mathrm{~m}$, and a constant distance $(5 \mathrm{~m})$ between two 
Fig. 13 Different configurations of borehole heat exchangers [190]

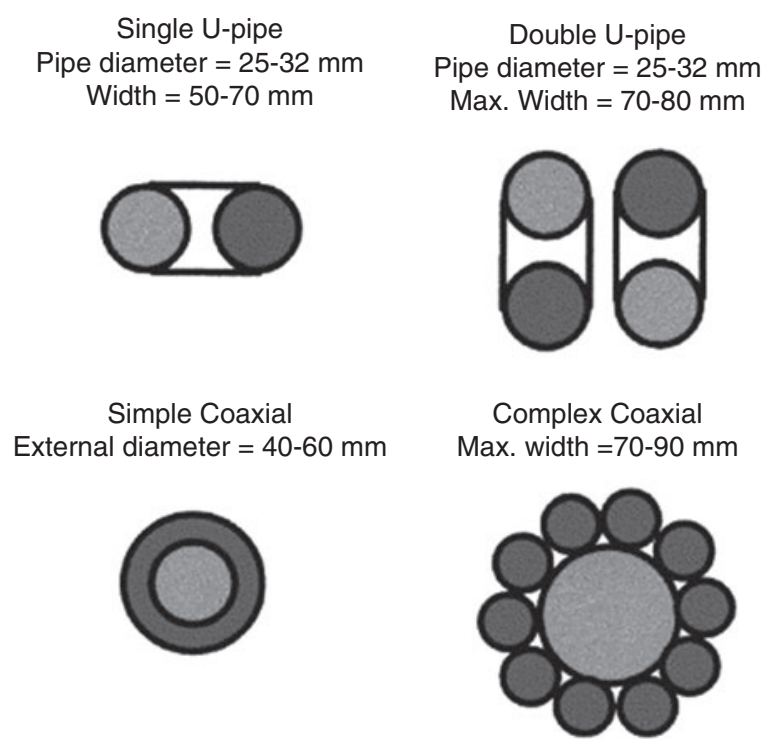

boreholes. The possibility of thermal energy storage in shallow trenches filled with encapsulated PCMs is also studied by [191].

Some efforts in the literature focused on reducing the contact thermal resistance between the pipes and the borehole wall by using filling grouting materials with high thermal conductivity. These grouting materials include bentonite or high solid composite (such as 9\% blast furnace cement, 9\% Poland cement, 32\% fine silica sand, and 50\% water) [192], water alone [193], and a composite material with graphite additive [194].

Borehole TES concept has received considerable attention for large-scale seasonal TES plants owing to its adaptive feature (no specific requirements for the locations) and its possibility for a modular design [152]. Due to its lower energy storage density than water-based TES concepts, a borehole TES system requires 3-5 times more volume to reach the same amount of stored energy. The payback time estimated ranges between 5 and 10 years, which is also higher than that of aquifer TES systems, mainly due to the significantly high initial cost (cost of borehole tubes and ground work) and the long time to reach typical performance [195]. Table 6 presents the technical data for some typical seasonal TES plants using borehole technology.

\section{Comparison between Different Sensible Seasonal TES Technologies}

Based on the above discussion, it may be seen that different sensible TES technologies have been already widely applied for seasonal storage, preferentially in largescale heating/cooling plants than in single-family houses. This is because the investment cost (per water equivalent) decreases as the storage volume increases [159]. The costs of water-tank or gravel-water concepts are relatively higher due to the construction of water tank/pit and the ground work. Borehole and aquifer TES 
Table 6 Technical data on the seasonal borehole TES plants

\begin{tabular}{|c|c|c|c|c|}
\hline Plant & $\begin{array}{l}\text { Heated } \\
\text { living area } \\
\left(\mathrm{m}^{2}\right)\end{array}$ & $\begin{array}{l}\text { Solar } \\
\text { collector } \\
\text { area }\left(\mathrm{m}^{2}\right)\end{array}$ & Borehole storage volume $\left(\mathrm{m}^{3}\right)$ & REF \\
\hline $\begin{array}{l}\text { Neckarsulm } \\
\text { Germany }\end{array}$ & 20,000 & 5470 & $\begin{array}{l}63,360 \text { (doubled in U-shape duct } \\
\text { of } 30 \mathrm{~m} \text { deep) }\end{array}$ & [152] \\
\hline $\begin{array}{l}\text { Attenkirchen } \\
\text { Germany }\end{array}$ & 30 homes & 863 & $\begin{array}{l}500 \text { (hot water) }+ \\
10,500 \text { (borehole) ( } 90 \text { borehole } \\
\text { double-U-loops of } 30 \mathrm{~m} \text { deep) }\end{array}$ & [196] \\
\hline $\begin{array}{l}\text { Crailsheim } \\
\text { Germany }\end{array}$ & $\begin{array}{l}\text { School and } \\
\text { gymnasium }\end{array}$ & $\begin{array}{l}7300 \\
\text { (vacuum } \\
\text { tubes) }\end{array}$ & $\begin{array}{l}37,500 \text { (double U-pipes, } 80 \\
\text { boreholes with a depth of } 55 \mathrm{~m} \text { ) }\end{array}$ & [197] \\
\hline $\begin{array}{l}\text { Anneberg } \\
\text { Sweden }\end{array}$ & $\begin{array}{l}50 \\
\text { residential } \\
\text { units }\end{array}$ & 2400 & $\begin{array}{l}60,000 \text { (crystalline rock; double } \\
\text { U-pipes; } 100 \text { boreholes with a } \\
\text { depth of } 65 \mathrm{~m} \text { ) }\end{array}$ & [195] \\
\hline $\begin{array}{l}\text { Lidköping } \\
\text { Sweden }\end{array}$ & & 2500 & 15,000 (clay) & [186] \\
\hline $\begin{array}{l}\text { Kungsbacka } \\
\text { Sweden }\end{array}$ & $\begin{array}{l}\text { School } \\
\text { building }\end{array}$ & 1500 & 85,000 & [197] \\
\hline $\begin{array}{l}\text { Drake } \\
\text { landing solar } \\
\text { community } \\
\text { Canada }\end{array}$ & 52 homes & 2313 & $\begin{array}{l}33,657(144 \text { boreholes with a } \\
\text { depth of } 35 \mathrm{~m})\end{array}$ & [192] \\
\hline $\begin{array}{l}\text { Treviglio } \\
\text { Italy }\end{array}$ & $\begin{array}{l}\text { Residential } \\
\text { area }\end{array}$ & 2727 & 43,000 & [186] \\
\hline $\begin{array}{l}\text { Groningen } \\
\text { Netherlands }\end{array}$ & $\begin{array}{l}\text { Residential } \\
\text { area }\end{array}$ & 2400 & 23,000 & {$[186,197]$} \\
\hline $\begin{array}{l}\text { Kranebitten } \\
\text { Austria }\end{array}$ & & 400 & 60,000 & [198] \\
\hline $\begin{array}{l}\text { Shanghai } \\
\text { China }\end{array}$ & $\begin{array}{l}2304 \\
\text { (greenhouse) }\end{array}$ & $\begin{array}{l}500 \\
\text { (vacuum } \\
\text { tube) }\end{array}$ & $\begin{array}{l}4970(130 \text { U-pipes at a depth of } \\
10 \mathrm{~m})\end{array}$ & [204] \\
\hline $\begin{array}{l}\text { Harbin } \\
\text { China }\end{array}$ & $\begin{array}{l}500 \\
\text { (detached } \\
\text { houses) }\end{array}$ & 50 & $\begin{array}{l}5100(12 \text { single U-pipes at a depth } \\
\text { of } 50 \mathrm{~m})\end{array}$ & [199] \\
\hline
\end{tabular}

technologies are relatively cheaper in terms of initial cost but depend strongly on the geological conditions for their installation. Moreover, the influences of the drilled boreholes or aquifers on the underground hydro-geological and microbiological situations after yearly usage still need to be further investigated. Table 7 summaries the characteristics of each sensible seasonal TES technology and gives a comparison on their advantages and limitations.

Several R\&D problems still exist. Firstly, how to adjust the thermal interference (stratification) when heat or cold is charge into or discharged from the store requires further efforts of researchers. Secondly, the development of cost-effective insulation materials to reduce the thermal loss during the storage period is quite important. Since for seasonal TES, the temperature of heat stored is usually low and not sufficient to be directly used for space heating or DHW generation. The temperature 
Table 7 Comparison between different technologies of sensible seasonal TES [187, 204]

\begin{tabular}{|c|c|c|c|c|}
\hline Concept & Water tank & Gravel-water & Aquifer & Borehole \\
\hline $\begin{array}{l}\text { Storage } \\
\text { medium }\end{array}$ & Water & $\begin{array}{l}\text { Gravel and } \\
\text { water }\end{array}$ & $\begin{array}{l}\text { Water - Sand/ } \\
\text { gravel }\end{array}$ & Soil, rock, sand, etc. \\
\hline $\begin{array}{l}\text { Storage } \\
\text { capacity } \\
\left(\mathrm{kWh} / \mathrm{m}^{3}\right)\end{array}$ & $60-80$ & $30-50$ & $30-40$ & $15-30$ \\
\hline $\begin{array}{l}\text { Storage } \\
\text { volume } \\
\left(1 \mathrm{~m}^{3} \text { water }\right. \\
\text { equivalent })\end{array}$ & 1 & $1.3-2$ & $2-3$ & $3-5$ \\
\hline $\begin{array}{l}\text { Geological } \\
\text { requirements }\end{array}$ & \multicolumn{2}{|c|}{$\begin{array}{l}\text {-stable ground conditions } \\
\text {-preferably no ground water } \\
-5-15 \mathrm{~m} \text { deep }\end{array}$} & $\begin{array}{l}\text {-natural aquifer } \\
\text { layer with high } \\
\text { hydraulic } \\
\text { conductivity } \\
\left(k_{f}>1 \times 10^{-5} \mathrm{~m} / \mathrm{s}\right) \\
\text {-confining layers } \\
\text { on top and bottom } \\
\text {-no or low natural } \\
\text { groundwater flow } \\
\text {-suitable water } \\
\text { chemistry at high } \\
\text { temperature } \\
\text {-aquifer thickness } \\
\text { between } 20 \text { and } \\
50 \text { m deep }\end{array}$ & $\begin{array}{l}\text {-drillable ground } \\
\text {-groundwater } \\
\text { favorable } \\
\text {-medium to high } \\
\text { thermal conductivity } \\
\text {-high heat capacity } \\
\text {-30-100 m deep }\end{array}$ \\
\hline Advantages & $\begin{array}{l}\text { - Can be } \\
\text { built at } \\
\text { almost any } \\
\text { location } \\
\text { - Most } \\
\text { common } \\
\text { system } \\
\text { - No special } \\
\text { geological } \\
\text { condition } \\
\text { requirements } \\
\text { - High } \\
\text { stratification } \\
\text { - High heat } \\
\text { capacity } \\
\text { - Easy } \\
\text { installation }\end{array}$ & $\begin{array}{l}\text { - Can be built } \\
\text { almost } \\
\text { everywhere } \\
\text { - No special } \\
\text { geological } \\
\text { condition } \\
\text { requirements } \\
\text { - More cost } \\
\text { effective than } \\
\text { water tank } \\
\text { - Leaving } \\
\text { natural aquifer } \\
\text { untouched }\end{array}$ & $\begin{array}{l}\text { - Cost effective } \\
\text { - Can be used for } \\
\text { both heating and } \\
\text { cooling } \\
\text { - Ability to } \\
\text { produce direct } \\
\text { cooling without } \\
\text { using any } \\
\text { supporting device } \\
\text { - Low } \\
\text { maintenance cost } \\
\text { - Much more } \\
\text { efficient heat } \\
\text { transfer compared } \\
\text { to borehole TES }\end{array}$ & $\begin{array}{l}\text { - Can be used for both } \\
\text { heating and cooling } \\
\text { - for vertical borehole } \\
\text { ( } 30-200 \mathrm{~m} \text { depth with } \\
\text { the spacing of about } \\
2-4 \mathrm{~m} \text { ), less surface } \\
\text { area is needed } \\
\text { - less sensitive to } \\
\text { outdoor climate due to } \\
\text { constant ground } \\
\text { temperature } \\
\text { - For horizontal duct } \\
\text { (at depth of } 0.8 \text { to } \\
1.5 \text { m), less excavation } \\
\text { is needed thus lower } \\
\text { cost } \\
\text { - Feasible for very } \\
\text { large and very small } \\
\text { applications }\end{array}$ \\
\hline
\end{tabular}


Table 7 (continued)

\begin{tabular}{|c|c|c|c|c|}
\hline Concept & Water tank & Gravel-water & Aquifer & Borehole \\
\hline Limitations & $\begin{array}{l}\text { - High cost } \\
\text { in buried } \\
\text { water tank } \\
\text { - High } \\
\text { thermal loss } \\
\text { - Corrosion } \\
\text { - Leakage }\end{array}$ & $\begin{array}{l}\text { - High cost } \\
\text { - Low } \\
\text { stratification } \\
\text { due to high } \\
\text { thermal } \\
\text { conductivity } \\
\text { - Leakage } \\
\text { - Needs 1.3-2 } \\
\text { times larger } \\
\text { storage volume } \\
\text { compared to } \\
\text { water tank }\end{array}$ & $\begin{array}{l}\text { - Needs special } \\
\text { geological } \\
\text { conditions } \\
\text { - High thermal } \\
\text { loss due to no } \\
\text { thermal insulation } \\
\text { - Needs 2-3 times } \\
\text { larger storage } \\
\text { volume compared } \\
\text { to water tank } \\
\text { - Clogging effects } \\
\text { - Long initial } \\
\text { process due to } \\
\text { extensive } \\
\text { geological } \\
\text { investigation }\end{array}$ & $\begin{array}{l}\text { - Needs } 3-5 \text { times } \\
\text { larger storage volume } \\
\text { compared to water tank } \\
\text { - Not suitable for all } \\
\text { locations with ground- } \\
\text { water flow } \\
\text { - Needs drillable } \\
\text { ground } \\
\text { - High initial cost } \\
\text { - 3-4 years needed to } \\
\text { reach typical } \\
\text { performance }\end{array}$ \\
\hline
\end{tabular}

upgrading via the coupling with a heat pump system or a supplementary boiler is indispensable. Hence, the system integration/regulation and the control strategy should be carefully designed and optimized.

\section{Conclusions and Future Directions}

This chapter presents currently available technologies by sensible heat for both short-term and long-term TES for buildings. Based on the literature review, the following conclusions may be achieved:

- Compared to latent or thermochemical TES, sensible technologies are relatively simple, easy to handle, cost-effective, and have found their positions in building applications both for short-term and long-term TES storage.

- Commonly used sensible technologies for daily TES in buildings include water tank, packed bed, thermal mass, thermally activated building system, and solar wall. They are oriented for both single-family houses and for multiple-family districts. The most developed and widely used is water tank, whereas others are good complementary depending on locations, weather conditions, or buildings. The development of super insulation for water tanks and the methods to maintain the thermal stratification inside the tank are currently the main R\&D focuses.

- Commonly used sensible technologies for seasonal TES in buildings include water tank, gravel-water, aquifer, and borehole technologies. From the economic point of view, they are more cost-effective for large-scale applications. The selection of the technology mainly depends on the hydro-geological conditions of the sites. The main R\&D focuses are the system integration/regulation when they are coupled with renewable sources or heat pumps. 
Table 8 Key data and figures for sensible TES technologies (Adapted from Ref. [200])

\begin{tabular}{l|l}
\hline $\begin{array}{l}\text { Technical } \\
\text { performance }\end{array}$ & Typical current international values and ranges \\
\hline Energy input & $\begin{array}{l}\text { Solar heat, waste heat, variable renewable energy sources }(\mathrm{PV}, \text { wind, } \\
\text { geothermal, etc.), cooking heat, etc. }\end{array}$ \\
\hline Energy output & Space heating/cooling, domestic hot water generation \\
\hline Storage capacity & $10-50(\mathrm{kWh} / \mathrm{t})$ \\
\hline Thermal power & $0.001-10(\mathrm{mw})$ \\
\hline Efficiency & $50-90(\%)$ \\
\hline Storage period & Daily, monthly, yearly \\
\hline Cost & $0.1-10(€ / \mathrm{kWh})$ \\
\hline $\begin{array}{l}\text { Technical } \\
\text { lifetime }\end{array}$ & $10-30+($ year $)$ \\
\hline $\begin{array}{l}\text { Environmental } \\
\text { impact }\end{array}$ & $\begin{array}{l}\text { Negligible, with greenhouse gas emission reduction depending on the } \\
\text { amount of primary fossil energy saved by using energy storage. } \\
\text { environmental impact of large-scale underground TES systems is still not } \\
\text { very clear }\end{array}$ \\
\hline
\end{tabular}

Table 8 provides an estimation of IEA on the current status of development for sensible TES technologies (Adapted from Ref. [200]).

Several directions for the future development are also identified for sensible TES, for the purpose of augmenting its market share for building applications.

- Coupling with PCMs (layers, encapsulates, etc.) to improve the energy density.

- Coupling with variable heat sources, especially renewable heat sources.

- Coupling with heat pumps for its temperature up-grading, especially for seasonal storage.

- System integration, optimized control strategy for best energy savings.

\section{References}

1. Hoes P, Trcka M, Hensen JLM, Hoekstra Bonnema B (2011) Investigating the potential of a novel low-energy house concept with hybrid adaptable thermal storage. Energy Convers Manag 52(6):2442-2447

2. Buonomano A, Calise F, Palombo A, Vicidomini M (2015) Energy and economic analysis of geothermal-solar trigeneration systems: A case study for a hotel building in Ischia. Appl Energy 138:224-241

3. Tsoutsou S, Infante Ferreira C, Krieg J, Ezzahiri M (2014) Building integration of concentrating solar systems for heating applications. Appl Therm Eng 70(1):647-654

4. Radcoind. http://www.radcoind.com/industrial-energy/

5. Therminol. https://www.therminol.com/french

6. Duratherm. https://durathermfluids.com/heat-transfer-fluid/

7. Dow. http://www.dow.com/heattrans/products/

8. Tatsidjodoung P, Le Pierrès N, Luo L (2013) A review of potential materials for thermal energy storage in building applications. Renew Sust Energ Rev 18:327-349

9. Gutierrez A, Miró L, Gil A, Rodríguez-Aseguinolaza J, Barreneche C, Calvet N, Py X, Inés Fernández A, Grágeda M, Ushak S, Cabeza LF (2016) Advances in the valorization of waste 
and by-product materials as thermal energy storage (TES) materials. Renew Sust Energ Rev 59:763-783

10. Navarro ME, Martínez M, Gil A, Fernández AI, Cabeza LF, Olives R, Py X (2012) Selection and characterization of recycled materials for sensible thermal energy storage. Sol Energy Mater Sol Cells 107:131-135

11. Py X, Calvet N, Olives R, Meffre A, Echegut P, Bessada C, Veron E, Ory S (2011) Recycled material for sensible heat based thermal energy storage to be used in concentrated solar thermal power plants. J Solar Energy Eng Trans ASME 133(3):Art. no. 031008

12. Jeanjean A, Olives R, Py X (2013) Selection criteria of thermal mass materials for low-energy building construction applied to conventional and alternative materials. Energ Buildings 63:36-48

13. Ortega I, Faik A, Gil A, Rodríguez-Aseguinolaza J, D'Aguanno B (2015) Thermo-physical Properties of a Steel-making by-product to be used as Thermal Energy Storage Material in a Packed-bed System. Energy Procedia 69:968-977

14. Agalit H, Zari N, Maalmi M, Maaroufi M (2015) Numerical investigations of high temperature packed bed TES systems used in hybrid solar tower power plants. Sol Energy 122:603-616

15. Calvet N, Dejean G, Unamunzaga L, Py X (2013) Waste from metallurgic industry: A sustainable high-temperature thermal energy storage material for concentrated solar power. ASME 2013 7th Internatinal Conference on Energy Sustainability Collocated with the ASME 2013 Heat Transfer Summer Conference and the ASME 2013 11th International Conference on Fuel Cell Science, Engineering and Technology, ES 2013, art. no. V001T03A012

16. Ghosh J, Mondal AK, Singh N, Das SK (2011) Evaluation of iron ore tailings for the production of building materials. Ind Ceram 31(2):115-119

17. Miró L, Navarro ME, Suresh P, Gil A, Fernández AI, Cabeza LF (2014) Experimental characterization of a solid industrial by-product as material for high temperature sensible thermal energy storage (TES). Appl Energy 113:1261-1268

18. Osman K, Al Khaireed SMN, Ariffin MK, Senawi MY (2008) Dynamic modeling of stratification for chilled water storage tank. Energy Convers Manag 49(11):3270-3273

19. Yan C, Shi W, Li X, Zhao Y (2016) Optimal design and application of a compound cold storage system combining seasonal ice storage and chilled water storage. Appl Energy $171: 1-11$

20. Chan ALS, Chow TT, Fong SKF (2006) Lin, J.Z. Performance evaluation of district cooling plant with ice storage. Energy 31(14):2414-2426

21. Sebzali MJ, Rubini PA (2006) Analysis of ice cool thermal storage for a clinic building in Kuwait. Energy Convers Manag 47(18-19):3417-3434

22. Hamada Y, Kubota H, Nakamura M, Kudo K, Hashimoto Y (2010) Experiments and evaluation of a mobile high-density snow storage system. Energ Buildings 42(2):178-182

23. Bahadori MN (1985) Natural production, storage, and utilization of ice in deep ponds for summer air conditioning. Sol Energy 34(2):143-149

24. Kirkpatrick DL, Masoero M, Rabl A, Roedder CE, Socolow RH, Taylor TB (1985) The ice pond-production and seasonal storage of ice for cooling. Sol Energy 35(5):435-445

25. Mastouri H, Benhamou B, Hamdi H (2013) Pebbles bed thermal storage for heating and cooling of buildings. Energy Procedia 42:761-764

26. Ashby M (2005) Materials Selection in Mechanical Design, 3rd edn. Elsevier, Oxford

27. Fernandez AI, Martnez M, Segarra M, Martorell I, Cabeza LF (2010) Selection of materials with potential in sensible thermal energy storage. Sol Energy Mater Sol Cells 94(10):1723-1729

28. Sateikis I (2002) Determination of the amount of thermal energy in the tanks of buildings heating systems. Energ Buildings 34(4):357-361

29. Rasoul Asaee S, Ismet Ugursal V, Beausoleil-Morrison I (2017) Techno-economic feasibility evaluation of air to water heat pump retrofit in the Canadian housing stock. Appl Therm Eng 111:936-949 
30. Votsis PP, Tassou SA, Wilson DR, Marquand CJ (1988) Experimental and Theoretical Investigation of Mixed and Stratified Hot Water Storage Tanks. Proc Inst Mech Eng C J Mech Eng Sci 202(3):187-193

31. Campos Celador A, Odriozola M, Sala JM (2011) Implications of the modelling of stratified hot water storage tanks in the simulation of CHP plants. Energy Convers Manag 52(8-9):3018-3026

32. Mongibello L, Capezzuto M, Graditi G (2014) Technical and cost analyses of two different heat storage systems for residential micro-CHP plants. Appl Therm Eng 71(2):636-642

33. Perea E, Ruiz N, Cobelo I, Lizuain Z, Carrascal A (2016) A novel optimization algorithm for efficient economic dispatch of Combined Heat and Power devices. Energ Buildings 111:507-514

34. Rosato A, Sibilio S, Scorpio M (2014) Dynamic performance assessment of a residential building-integrated cogeneration system under different boundary conditions. Part II: Environmental and economic analyses. Energy Convers Manag 79:749-770

35. Thiers S, Aoun B, Peuportier B (2010) Experimental characterization, modeling and simulation of a wood pellet micro-combined heat and power unit used as a heat source for a residential building. Energ Buildings 42(6):896-903

36. Calise F, d'Accadia MD, Vanoli L (2012) Design and dynamic simulation of a novel solar trigeneration system based on hybrid photovoltaic/thermal collectors (PVT). Energy Convers Manag 60:214-225

37. Calise F, d'Accadia MD, Palombo A, Vanoli L (2013) Dynamic simulation of a novel hightemperature solar trigeneration system based on concentrating photovoltaic/thermal collectors. Energy 61:72-86

38. Eicker U, Dalibard A (2011) Photovoltaic-thermal collectors for night radiative cooling of buildings. Sol Energy 85(7):1322-1335

39. Mammoli A, Vorobieff P, Barsun H, Burnett R, Fisher D (2010) Energetic, economic and environmental performance of a solar-thermal-assisted HVAC system. Energ Buildings 42 (9):1524-1535

40. Rosiek S, Batlles FJ (2011) Performance study of solar-assisted air-conditioning system provided with storage tanks using artificial neural networks. Int J Refrig 34(6):1446-1454

41. Lazaar M, Bouadila S, Kooli S, Farhat A (2015) Comparative study of conventional and solar heating systems under tunnel Tunisian greenhouses: Thermal performance and economic analysis. Sol Energy 120:620-635

42. Lohrenz E, Almeida S (2013) Ground-Coupled Heat Pump And Energy Storage. ASHRAE J 55(4):14-22

43. Calise F (2011) Design of a hybrid polygeneration system with solar collectors and a Solid Oxide Fuel Cell: Dynamic simulation and economic assessment. Int $\mathbf{J}$ Hydrog Energy 36(10):6128-6150

44. Nanaeda K, Mueller F, Brouwer J, Samuelsen S (2009) Dynamic modeling of a solid oxide fuel cell combined heat and power system with thermal storage for commercial building applications, Proceedings of ASME. Seventh International Fuel Cell Science, Engineering and Technology Conference FuelCell2009, 8-10 June 2009, Newport Beach

45. Pisello AL, Petrozzi A, Castaldo VL, Cotana F (2016) On an innovative integrated technique for energy refurbishment of historical buildings: Thermal-energy, economic and environmental analysis of a case study. Appl Energy 162:1313-1322

46. Zhao Y, Lu Y, Yan C, Wang S (2015) MPC-based optimal scheduling of grid-connected low energy buildings with thermal energy storages. Energ Buildings 86:415-426

47. Balghouthi M, Chahbani MH, Guizani A (2012) Investigation of a solar cooling installation in Tunisia. Appl Energy 98:138-148

48. Baniyounes AM, Rasul MG, Khan MMK (2013) Assessment of solar assisted air conditioning in Central Queensland's subtropical climate, Australia. Renew Energy 50:334-341 
49. Fong KF, Lee CK (2015) Investigation of separate or integrated provision of solar cooling and heating for use in typical low-rise residential building in subtropical Hong Kong. Renew Energy 75:847-855

50. Reda F, Viot M, Sipilä K, Helm M (2016) Energy assessment of solar cooling thermally driven system configurations for an office building in a Nordic country. Appl Energy 166:27-43

51. Syed A, Izquierdo M, Rodríguez P, Maidment G, Missenden J, Lecuona A, Tozer R (2005) A novel experimental investigation of a solar cooling system in Madrid. Int $J$ Refrig 28(6):859-871

52. He W, Zhou J, Hou J, Chen C, Ji J (2013) Theoretical and experimental investigation on a thermoelectric cooling and heating system driven by solar. Appl Energy 107:89-97

53. Roth (2013) Thermotank Quadroline: the new generation of plastic storage tanks. http://www. roth-werke.de/en/files/WS_Thermotank_2013_EN.pdf

54. Koehl M, Saile S, Piekarczyk A, Fischer S (2014) Task 39 Exhibition - Assembly of Polymeric Components for a New Generation of Solar Thermal Energy Systems. Energy Procedia 48:130-136

55. Choudhury C, Garg HP (1992) Thermal performance of a solar hybrid domestic hot water system. Energy 17(7):703-711

56. Zauner C, Stift F, Hartl M, Themessl T, Manglberger S, Simetzberger A (2014) Energy Labeling and Advanced Insulation for Thermal Energy Storages in Solar Applications. Energy Procedia 57:2352-2359

57. Kamiuto K, Miyamoto T, Saitoh S (1999) Thermal characteristics of a solar tank with aerogel surface insulation. Appl Energy 62(3):113-123

58. Fuchs B, Hofbeck K, Faulstich M (2012) Vacuum insulation panels - A promising solution for high insulated tanks. Energy Procedia 30:424-427

59. Ghaddar NK (1994) Stratified storage tank influence on performance of solar water heating system tested in Beirut. Renew Energy 4(8):911-925

60. Eames PC, Norton B (1998) The effect of tank geometry on thermally stratified sensible heat storage subject to low Reynolds number flows. Int J Heat Mass Transf 41(14):2131-2142

61. Njoku HO, Ekechukwu OV, Onyegegbu SO (2016) Comparison of energy, exergy and entropy generation-based criteria for evaluating stratified thermal store performances. Energ Buildings 124:141-152

62. Al-Najem NM, El-Refaee MM (1997) A numerical study for the prediction of turbulent mixing factor in thermal storage tanks. Appl Therm Eng 17(12):1173-1181

63. Furbo S, Andersen E, Thür A, Shah LJ, Andersen KD (2005) Performance improvement by discharge from different levels in solar storage tanks. Sol Energy 79(5):431-439

64. Lavan Z, Thompson J (1977) Experimental study of thermally stratified hot water storage tanks. Sol Energy 19(5):519-524

65. Li S, Zhang Y, Li Y, Zhang X (2014) Experimental study of inlet structure on the discharging performance of a solar water storage tank. Energ Buildings 70:490-496

66. Zachár A, Farkas I, Szlivka F (2003) Numerical analyses of the impact of plates for thermal stratification inside a storage tank with upper and lower inlet flows. Sol Energy 74(4):287-302

67. Knudsen S, Furbo S (2004) Thermal stratification in vertical mantle heat-exchangers with application to solar domestic hot-water systems. Appl Energy 78(3):257-272

68. Rosen MA (2001) The exergy of stratified thermal energy storages. Sol Energy 71(3):173-185

69. van Berkel J, Rindt CCM, van Steenhoven AA (2002) Thermocline dynamics in a thermally stratified store. Int J Heat Mass Transf 45(2):343-356

70. Altuntop N, Arslan M, Ozceyhan V, Kanoglu M (2005) Effect of obstacles on thermal stratification in hot water storage tanks. Appl Therm Eng 25(14-15):2285-2298

71. Shah LJ, Furbo S (2003) Entrance effects in solar storage tanks. Sol Energy 75(4):337-348

72. Yee CK, Lai FC (2001) Effects of a porous manifold on thermal stratification in a liquid storage tank. Sol Energy 71(4):241-254

73. Han YM, Wang RZ, Dai YJ (2009) Thermal stratification within the water tank. Renew Sust Energ Rev 13(5):1014-1026 
74. Swiatek M, Fraisse G, Pailha M (2015) Stratification enhancement for an integrated collector storage solar water heater (ICSSWH). Energ Buildings 106:35-43

75. Garg HP, Sharma VK, Mahajan RB, Bhargave AK (1985) Experimental study of an inexpensive solar collector cum storage system for agricultural uses. Sol Energy 35(4):321-331

76. Hamdan MA (1998) Investigation of an inexpensive solar collector storage system. Energy Convers Manag 39(5-60):415-420

77. Joudi KA, Dhaidan NS (2001) Application of solar assisted heating and desiccant cooling systems for a domestic building. Energy Convers Manag 42(8):995-1022

78. Singh PL, Deshpandey SD, Jena PC (2015) Thermal performance of packed bed heat storage system for solar air heaters. Energy Sustain Dev 29:112-117

79. Michelson E, Shitzer A (1986) Is there a need for a rock bed store? Simulation and optimization of solar air heating systems for offices with large thermal capacity walls. Sol Energy 36(2):99-114

80. Singh H, Saini RP, Saini JS (2010) A review on packed bed solar energy storage systems. Renew Sust Energ Rev 14(3):1059-1069

81. Sorour MM (1988) Performance of a small sensible heat energy storage unit. Energy Convers Manag 28(3):211-217

82. Ammar ASA, Ghoneim AA (1991) Optimization of a sensible heat storage unit packed with spheres of a local material. Renew Energy 1(1):91-95

83. Sagara K, Nakahara N (1991) Thermal performance and pressure drop of rock beds with large storage materials. Sol Energy 47(3):157-163

84. Audi MS (1992) Experimental study of a solar space heating model using Jordanian rocks for storage. Energy Convers Manag 33(9):833-842

85. Crandall DM, Thacher EF (2004) Segmented thermal storage. Sol Energy 77(4):435-440

86. Choudhury C, Garg HP (1995) Integrated rock bed heat exchanger-cum-storage unit for residential-cum-water heating. Energy Convers Manag 36(10):999-1006

87. Al-Juwayhel F, El-Refaee MM (1998) Thermal performance of a combined packed bed-solar pond system - a numerical study. Appl Therm Eng 18(12):1207-1223

88. Ogoli DM (2003) Predicting indoor temperatures in closed buildings with high thermal mass. Energ Buildings 35(9):851-862

89. Reddy TA, Norford LK, Kempton W (1991) Shaving residential air-conditioner electricity peaks by intelligent use of the building thermal mass. Energy 16(7):1001-1010

90. Li X, Wen J, Malkawi A (2016) An operation optimization and decision framework for a building cluster with distributed energy systems. Appl Energy 178:98-109

91. Hacker JN, De Saulles TP, Minson AJ, Holmes MJ (2008) Embodied and operational carbon dioxide emissions from housing: A case study on the effects of thermal mass and climate change. Energ Buildings 40(3):375-384

92. Ip K, Miller A (2009) Thermal behaviour of an earth-sheltered autonomous building - the Brighton Earthship. Renew Energy 34(9):2037-2043

93. Akbari H, Samano D, Mertol A, Bauman F, Kammerud R (1986) The effect of variations in convection coefficients on thermal energy storage in buildings Part I - Interior partition walls. Energ Buildings 9(3): 195-211

94. Akbari H, Samano D, Mertol A, Bauman F, Kammerud R (1987) The effect of variations in convection coefficients on thermal energy storage in buildings Part II - Exterior massive walls and simulations. Energ Buildings 10(1):29-47

95. Yam J, Li Y, Zheng Z (2003) Nonlinear coupling between thermal mass and natural ventilation in buildings. Int J Heat Mass Transf 46(7):1251-1264

96. Ma P, Wang LS (2012) Effective heat capacity of interior planar thermal mass (iPTM) subject to periodic heating and cooling. Energ Buildings 47:44-52

97. Li W, Xu P, Wang H, Lu X (2016) A new method for calculating the thermal effects of irregular internal mass in buildings under demand response. Energ Buildings 130:761-772

98. Raftery P, Lee E, Webster T, Hoyt T, Bauman F (2014) Effects of furniture and contents on peak cooling load. Energ Buildings 85:445-457 
99. Marsh J (2010) Context and future climate: a single house case study. In: Proceedings of Sustainable Energy Technologies 2010, Shanghai

100. Henze GP, Pfafferott J, Herkel S, Felsmann C (2007) Impact of adaptive comfort criteria and heat waves on optimal building thermal mass control. Energ Buildings 39(2):221-235

101. Lee K, Braun JE (2008) Model-based demand-limiting control of building thermal mass. Build Environ 43(10):1633-1646

102. Li X, Malkawi A (2016) Multi-objective optimization for thermal mass model predictive control in small and medium size commercial buildings under summer weather conditions. Energy 112:1194-1206

103. Le Dréau J, Heiselberg P (2016) Energy flexibility of residential buildings using short term heat storage in the thermal mass. Energy 111:991-1002

104. Hoes P, Hensen JLM (2016) The potential of lightweight low-energy houses with hybrid adaptable thermal storage: Comparing the performance of promising concepts. Energ Buildings 110:79-93

105. Johra H, Heiselberg P (2017) Influence of internal thermal mass on the indoor thermal dynamics and integration of phase change materials in furniture for building energy storage: A review. Renew Sust Energ Rev 69:19-32

106. Rhee KN, Kim KW (2015) A 50 year review of basic and applied research in radiant heating and cooling systems for the built environment. Build Environ 91:166-190

107. Bansal NK (1998) India, Characteristic parameters of a hypocaust construction. Build Environ 34(3):305-318

108. Zhuang Z, Li Y, Chen B (2009) Thermal storage performance analysis on Chinese kangs. Energ Buildings 41(4):452-459

109. Zhuang Z, Li Y, Chen B, Guo J (2009) Chinese kang as a domestic heating system in rural northern China-A review. Energ Buildings 41(1):111-119

110. Zhou G, He J (2015) Thermal performance of a radiant floor heating system with different heat storage materials and heating pipes. Appl Energy 138:648-660

111. Chu WK, Kim MS, Lee KT, Bhandari B, Lee GY, Yoon HS, Kim YS, Park JI, Bilegt E, Lee JY, Song JH, Park GH, Bhandari P, Lee CS, Song C, Ahn SH (2017) Design and performance evaluation of Korean traditional heating system - Ondol: Case study of Nepal. Energ Buildings 138:406-414

112. Krzaczek M, Kowalczuk Z (2011) Thermal Barrier as a technique of indirect heating and cooling for residential buildings. Energ Buildings 43(4):823-837

113. Ma P, Wang L, Guo N (2015) Energy storage and heat extraction - From thermally activated building systems (TABS) to thermally homeostatic buildings. Renew Sust Energ Rev 45:677-685

114. Navarro L, de Gracia A, Castell A, Álvarez S, Cabeza LF (2014) Design of a Prefabricated Concrete Slab with PCM Inside the Hollows. Energy Procedia 57:2324-2332

115. Jin X, Zhang X (2011) Thermal analysis of a double layer phase change material floor. Appl Therm Eng 31(10):1576-1581

116. Pomianowski M, Heiselberg P, Jensen RL (2012) Dynamic heat storage and cooling capacity of a concrete deck with PCM and thermally activated building system. Energ Buildings 53:96-107

117. Yang M, Yang X, Wang P, Shan M, Deng J (2013) A new Chinese solar kang and its dynamic heat transfer model. Energ Buildings 62:539-549

118. Yang M, Yang X, Wang Z, Wang P (2014) Thermal analysis of a new solar kang system. Energ Buildings 75:531-537

119. Fraisse G, Johannes K, Trillat-Berdal V, Achard G (2006) The use of a heavy internal wall with a ventilated air gap to store solar energy and improve summer comfort in timber frame houses. Energ Buildings 38(4):293-302

120. Chen Y, Galal K, Athienitis AK (2010) Modeling, design and thermal performance of a BIPV/ T system thermally coupled with a ventilated concrete slab in a low energy solar house: Part 2, ventilated concrete slab. Sol Energy 84(11):1908-1919 
121. Chen Y, Athienitis AK, Galal K (2010) Modeling, design and thermal performance of a BIPV/ T system thermally coupled with a ventilated concrete slab in a low energy solar house: Part 1, BIPV/T system and house energy concept. Sol Energy 84(11):1892-1907

122. Kamel R, Ekrami N, Dash P, Fung A, Hailu G (2015) BIPV/T+ASHP: Technologies for NZEBs. Energy Procedia 78:424-429

123. Park SH, Chung WJ, Yeo MS, Kim KW (2014) Evaluation of the thermal performance of a Thermally Activated Building System (TABS) according to the thermal load in a residential building. Energ Buildings 73:69-82

124. Romaní J, Pérez G, de Gracia A (2017) Experimental evaluation of a heating radiant wall coupled to a ground source heat pump. Renew Energy 105:520-529

125. Yu T, Heiselberg P, Lei B, Pomianowski M, Zhang C, Jensen R (2015) Experimental investigation of cooling performance of a novel HVAC system combining natural ventilation with diffuse ceiling inlet and TABS. Energ Buildings 105:165-177

126. Yu T, Heiselberg P, Lei B, Zhang C, Pomianowski M, Jensen R (2016) Experimental study on the dynamic performance of a novel system combining natural ventilation with diffuse ceiling inlet and TABS. Appl Energy 169:218-229

127. Romaní J, de Gracia A, Cabeza LF (2016) Simulation and control of thermally activated building systems (TABS). Energ Buildings 127:22-42

128. Hordeski MF (2011) New technologies for energy efficiency. The Fair- mont Press, New York

129. Hatamipour MS, Abedi A (2008) Passive cooling systems in buildings: Some useful experiences from ancient architecture for natural cooling in a hot and humid region. Energy Convers Manag 49(8):2317-2323

130. Saadatian O, Sopian K, Lim CH, Asim N, Sulaiman MY (2012) Trombe walls: A review of opportunities and challenges in research and development. Renew Sust Energ Rev 16(8):6340-6351

131. Stazi F, Mastrucci A, di Perna C (2012) The behaviour of solar walls in residential buildings with different insulation levels: An experimental and numerical study. Energ Buildings 47:217-229

132. Gan G (2006) Simulation of buoyancy-induced flow in open cavities for natural ventilation. Energ Buildings 38(5):410-420

133. Balcomb JD, McFarland RD (1978) A simple empirical method for estimating the performance of a passive solar heated building of the thermal storage wall type. Second National Passive Solar Conference, ISES, vol 1

134. NREL (2012) Building a better Trombe wall. Department of Energy's premier laboratory for renewable energy \& energy efficiency research, development and deployment, Colorado

135. Ozbalta TG, Kartal S (2010) Heat gain through Trombe wall using solar energy in a cold region of Turkey. Sci Res Essays 5:2768-2778

136. Gan G (1998) A parametric study of Trombe walls for passive cooling of buildings. Energ Buildings 27(1):37-43

137. Melero S, Morgado I, Neila J, Acha C (2011) Passive evaporative cooling by porous ceramic elements integrated in a Trombe wall. Magali Bodart AE, editor. Architecture \& sustainable development. Presses univ. de Louvain, In

138. Zalewski L, Lassue S, Duthoit B, Butez M (2002) Study of solar walls — validating a simulation model. Build Environ 37(1):109-121

139. Zrikem Z, Bilgen E (1987) Theoretical study of a composite Trombe-Michel wall solar collector system. Sol Energy 39(5):409-419

140. Sadineni SB, Madala S, Boehm RF (2011) Passive building energy savings: A review of building envelope components. Renew Sust Energ Rev 15(8):3617-3631

141. Sodha MS, Kaushik SC, Nayak JK (1981) Performance of trombe walls and roof pond systems. Appl Energy 8(3):175-191

142. Singh SR, Bansal NK (1983) Periodic analysis of a ventilated Trombe wall. Int J Energy Res $7(2): 163-172$ 
143. Kara YA, Kurnuç A (2012) Performance of coupled novel triple glass and phase change material wall in the heating season: An experimental study. Sol Energy 86(9):2432-2442

144. Lachheb M, Karkri M, Nasrallah SB (2015) Development and thermal characterization of an innovative gypsum-based composite incorporating phase change material as building energy storage system. Energ Buildings 107:93-102

145. Zalewski L, Joulin A, Lassue S, Dutil Y, Rousse D (2012) Experimental study of small-scale solar wall integrating phase change material. Sol Energy 86(1):208-219

146. Berthou Y, Biwole PH, Achard P, Sallée H, Tantot-Neirac M, Jay F (2015) Full scale experimentation on a new translucent passive solar wall combining silica aerogels and phase change materials. Sol Energy 115:733-742

147. Dehra H (2009) A two dimensional thermal network model for a photovoltaic solar wall. Sol Energy 83(11):1933-1942

148. Jie J, Hua Y, Gang P, Jianping L (2007) Study of PV-Trombe wall installed in a fenestrated room with heat storage. Appl Therm Eng 27(8-9):1507-1515

149. Sun W, Ji J, Luo C, He W (2011) Performance of PV-Trombe wall in winter correlated with south façade design. Appl Energy 88(1):224-231

150. Jiang B, Ji J, Yi H (2008) The influence of PV coverage ratio on thermal and electrical performance of photovoltaic-Trombe wall. Renew Energy 33(11):2491-2498

151. Duffie JA, Beckman WA (2013) Solar engineering of thermal processes, 4th edn. Wiley, Hoboken

152. Schmidt T, Mangold D, Müller-Steinhagen H (2004) Central solar heating plants with seasonal storage in Germany. Sol Energy 76(1-3):165-174

153. Kübler R, Fisch N, Hahne E (1997) High temperature water pit storage projects for the seasonal storage of solar energy. Sol Energy 61(2):97-105

154. Zhang HF, Ge XS, Ye H (2007) Modeling of a space heating and cooling system with seasonal energy storage. Energy 32(1):51-58

155. Karacavus B, Can A (2009) Thermal and economical analysis of an underground seasonal storage heating system in Thrace. Energ Buildings 41(1):1-10

156. Oliveti G, Arcuri N (1995) Prototype experimental plant for the interseasonal storage of solar energy for the winter heating of buildings: Description of plant and its functions. Sol Energy 54(2):85-97

157. Bauer D, Marx R, Nußbicker-Lux J, Ochs F, Heidemann W, Müller-Steinhagen H (2010) German central solar heating plants with seasonal heat storage. Sol Energy 84(4):612-623

158. Singh R, Mochizuki M, Mashiko K, Nguyen T (2011) Heat pipe based cold energy storage systems for datacenter energy conservation. Energy 36(5):2802-2811

159. Schmidt T, Mangold D, Müller-Steinhagen H (2003). Seasonal thermal energy storage in Germany. In: ISES Solar World Congress, 14-19 June, Göteborg

160. Williams GT, Attwater CR, Hooper FC (1980) A design method to determine the optimal distribution and amount of insulation for in-ground heat storage tanks. Sol Energy 24(5):471-475

161. Simons A, Firth SK (2011) Life-cycle assessment of a $100 \%$ solar fraction thermal supply to a European apartment building using water-based sensible heat storage. Energ Buildings 43(6): $1231-1240$

162. Schmidt T, Mangold D (2006) Status of solar thermal seasonal storage in Germany. ECOSTOCK '2006. In: 10th International Conference on Thermal Energy Storage, Stockton

163. Heller A (2000) 15 Years of R\&D in central solar heating in Denmark. Sol Energy 69(6):437-447

164. Dalenbäck JO, Jilar T (1985) Swedish solar heating with seasonal storage-design, performance and economy. Int J Amb Energy 6(3):123-128

165. Franke R (1997) Object-oriented modeling of solar heating systems. Sol Energy 60(3):171-180 
166. Oliveti G, Arcuri N, Ruffolo S (1998) First experimental results from a prototype plant for the interseasonal storage of solar energy for the winter heating of buildings. Sol Energy 62(4):281-290

167. Bokhoven TP, Van Dam J, Kratz P (2001) Recent experience with large solar thermal systems in The Netherlands. Sol Energy 71(50):347-352

168. Colclough S, Griffiths P (2016) Financial analysis of an installed small scale seasonal thermal energy store. Renew Energy 86:422-428

169. Novo AV, Bayon JR, Castro-Fresno D, Rodriguez-Hernandez J (2010) Review of seasonal heat storage in large basins: Water tanks and gravel-water pits. Appl Energy 87(2):390-397

170. Hahne E (2000) The ITW solar heating system: an oldtimer fully in action. Sol Energy 69(6):469-493

171. Lottner V, Schulz ME, Hahne E (2000) Solar-Assisted District Heating Plants: Status of the German Programme Solarthermie-2000. Sol Energy 69(6):449-459

172. Pfeil M, Koch H (2000) High performance-low cost seasonal gravel/water storage pit. Sol Energy 69(6):461-467

173. Pavlov GK, Olesen BW (2011) Seasonal grounds ola thermal energy storage-review of systems and applications. Proceedings of ISES Solar World Congress, Kassel

174. Seibt P, Kabus F (2006) Aquifer thermal energy storage - projects implemented in Germany. ECOSTOCK '2006. In: 10th International Conference on Thermal Energy Storage, Stockton

175. Nagano K, Mochida T, Ochifuji K (2002) Influence of natural convection on forced horizontal flow in saturated porous media for aquifer thermal energy storage. Appl Therm Eng 22(12):1299-1311

176. Zhou X, Gao Q, Chen X, Yu M, Zhao X (2013) Numerically simulating the thermal behaviors in groundwater wells of groundwater heat pump. Energy 61:240-247

177. Yapparova A, Matthäi S, Driesner T (2014) Realistic simulation of an aquifer thermal energy storage: Effects of injection temperature, well placement and groundwater flow. Energy 76:1011-1018

178. Kim J, Lee Y, Yoon WS, Jeon JS, Koo MH, Keehm Y (2010) Numerical modeling of aquifer thermal energy storage system. Energy 35(12):4955-4965

179. Bakr M, van Oostrom N, Sommer W (2013) Efficiency of and interference among multiple Aquifer Thermal Energy Storage systems; A Dutch case study. Renew Energy 60:53-62

180. Sommer W, Valstar J, Leusbrock I, Grotenhuis T, Rijnaarts H (2015) Optimization and spatial pattern of large-scale aquifer thermal energy storage. Appl Energy 137:322-337

181. Ganguly S, Kumar MSM, Date A, Akbarzadeh A (2017) Numerical investigation of temperature distribution and thermal performance while charging-discharging thermal energy in aquifer. Appl Therm Eng 115:756-773

182. Ghaebi H, Bahadori MN, Saidi MH (2014) Performance analysis and parametric study of thermal energy storage in an aquifer coupled with a heat pump and solar collectors, for a residential complex in Tehran, Iran. Appl Therm Eng 62(1):156-170

183. Hill M, DeHouche Z (2017) A comparative analysis of the effectiveness of aquifer thermal energy storage in Expeditionary Campaign Infrastructure. Appl Therm Eng 114:271-278

184. Vanhoudt D, Desmedt J, Van Bael J, Robeyn N, Hoes H (2011) An aquifer thermal storage system in a Belgian hospital: Long-term experimental evaluation of energy and cost savings. Energ Buildings 43(12):3657-3665

185. Morofsky E, Chant V, Hickling JF, Le Feuvre T (1984) Seasonal storage of building waste heat in an aquifer. In: Proceedings of the first E.C. conference on solar heating, 30 April-04 May, Amsterdam

186. Fisch MN, Guigas M, Dalenbäck JO (1998) A REVIEW OF LARGE-SCALE SOLAR HEATING SYSTEMS IN EUROPE. Sol Energy 63(6):355-366

187. Hesaraki A, Holmberg S, Haghighat F (2015) Seasonal thermal energy storage with heat pumps and low temperatures in building projects - a comparative review. Renew Sust Energ Rev 43:1199-1213 
188. Xiao X, Jiang Z, Owen D, Schrank C (2016) Numerical simulation of a high-temperature aquifer thermal energy storage system coupled with heating and cooling of a thermal plant in a cold region, China. Energy 112:443-456

189. Lanini S, Delaleux F, Py X, Olivès R, Nguyen D (2014) Improvement of borehole thermal energy storage design based on experimental and modelling results. Energ Buildings 77:393-400

190. Florides G, Kalogirou S (2007) Ground heat exchangers-A review of systems, models and applications. Renew Energy 32(15):2461-2478

191. Bottarelli M, Bortoloni M, Su Y (2015) Heat transfer analysis of underground thermal energy storage in shallow trenches filled with encapsulated phase change materials. Appl Therm Eng 90:1044-1051

192. Drake Landing Solar Community (2012) Borehole thermal energy storage (BTES). Available from: http://dlsc.ca

193. Gustafsson AM, Westerlund L, Hellström G (2010) CFD-modelling of natural convection in a groundwater-filled borehole heat exchanger. Appl Therm Eng 30(6-7):683-691

194. Delaleux F, Py X, Olives R, Dominguez A (2012) Enhancement of geothermal borehole heat exchangers performances by improvement of bentonite grouts conductivity. Appl Therm Eng 33-34:92-99

195. Lundh M, Dalenbäck JO (2008) Swedish solar heated residential area with seasonal storage in rock: Initial evaluation. Renew Energy 33(4):703-711

196. Reuss M, Beuth W, Schmidt M, Schoelkopf W (2006) Solar district heating with seasonal storage in Attenkirchen. ECOSTOCK'2006. In: 10th International Conference on Thermal Energy Storage, Stockton

197. Dalenbäck JO (2012) Available from: http://www.solar-district-heating.eu/SDH/LargeScaleSo larHeatingPlants.aspx

198. Chuard P, Hadorn JC (1983) Solar heating and cooling programme: IEA solar R\&D, task VII: centeral solar heating plants with seasonal storage

199. Wang X, Zheng M, Zhang W, Zhang S, Yang T (2010) Experimental study of a solar-assisted ground-coupled heat pump system with solar seasonal thermal storage in severe cold areas. Energ Buildings 42(11):2104-2110

200. IEA-ETSAP and IRENA (2013) Thermal Energy Storage Technology Brief E17. https://www. irena.org/DocumentDownloads/Publications/IRENA-ETSAP\%20Tech $\% 20 \mathrm{Brief} \% 20 \mathrm{E} 17 \%$ 20Thermal\%20Energy\%20Storage.pdf

201. Altwies JE, Reindl DT (2001) Passive thermal energy storage in refrigerated warehouses. Int J Refrig 24(1):149-157

202. Li G, Zheng X (2016) Thermal energy storage system integration forms for a sustainable future. Renew Sust Energ Rev 62:736-757

203. Paksoy HO, Andersson O, Abaci S, Evliya H, Turgut B (2000) Heating and cooling of a hospital using solar energy coupled with seasonal thermal energy storage in an aquifer. Renew Energy 19(1-2):117-122

204. Xu J, Wang RZ, Li Y (2014) A review of available technologies for seasonal thermal energy storage. Sol Energy 103:610-638

205. Xu X, Wang S, Wang J, Xiao F (2010) Active pipe-embedded structures in buildings for utilizing low-grade energy sources: A review. Energ Buildings 42(10):1567-1581

206. Xu X, Yu J, Wang S, Wang J (2014) Research and application of active hollow core slabs in building systems for utilizing low energy sources. Appl Energy 116:424-435

207. Zhu J, Chen B (2015) Experimental study on thermal response of passive solar house with color changed. Renew Energy 73:55-61

208. Lee, K., Lee, J., Yoon, E., Joo, M., Lee, S., \& Baek, N. (2014). Annual measured performance of building-integrated solar energy systems in demonstration low-energy solar house. Journal of Renewable and Sustainable Energy, 6(4), 04 2013. https://doi.org/10.1063/1.4893467

209. Chen TY (2001). Real-time predictive supervisory operation of building thermal systems with thermal mass. Energy and Buildings 33(2):141-150. https://doi.org/10.1016/S0378-7788(00) $00078-5$ 